OPEN ACCESS

Edited by:

Ryan Mathur,

Juniata College, United States

Reviewed by

Youye Zheng,

China University of Geosciences,

China

Fuquan Yang,

Institute of Biophysics (CAS), China

Hendrik Falck

Northwest Territories Geological

Survey, Canada

*Correspondence:

Xiao-Hua Deng

dxh198411@126.com

Specialty section:

This article was submitted to

Economic Geology,

a section of the journal

Frontiers in Earth Science

Received: 05 February 2021

Accepted: 23 August 2021

Published: 07 September 2021

Citation:

Xue $D$, Deng $X-H$, Bagas L, Chen X-A,

Wu Y-S and Jiang X (2021) Genesis of the Heiyanshan Tungsten Skarn

Deposit in the East Tianshan, NW

China: Insights From Geology, Fluid Inclusion, Isotopic Geochemistry and Geochronology.

Front. Earth Sci. 9:664603. doi: 10.3389/feart.2021.664603

\section{Genesis of the Heiyanshan Tungsten Skarn Deposit in the East Tianshan, NW China: Insights From Geology, Fluid Inclusion, Isotopic Geochemistry and Geochronology}

\author{
Dong Xue ${ }^{1,2}$, Xiao-Hua Deng ${ }^{2 *}$, Leon Bagas ${ }^{3,4}$, Xu-An Chen ${ }^{1}$, Yan-Shuang $W u^{5}$ and \\ Xiao Jiang ${ }^{6}$
}

${ }^{1}$ State Key Laboratory of Geological Processes and Mineral Resources, China University of Geosciences, Beijing, China, ${ }^{2}$ Beijing Institute of Geology for Mineral Resources Co., Ltd., Beijing, China, ${ }^{3}$ Centre for Exploration Targeting, The University of Western Australia, Crawley, WA, Australia, ${ }^{4}$ Key Laboratory for the Study of Focused Magmatism and Giant Ore Deposits of the Ministry of Natural Resources, Xi'an Center of China Geological Survey, Xi'an, China, ${ }^{5}$ State Key Laboratory of Desert and Oasis Ecology, Xinjiang Institute of Ecology and Geography, Chinese Academy of Sciences, Urumqi, China, ${ }^{6}$ No. 6 Geological Survey Team, Bureau of Xinjiang Geological Exploration, Hami, Urumqi, China

The eastern Tianshan Terrane is a highly prospective zone that contains several porphyry $\mathrm{Cu}-\mathrm{Mo}$, VMS Cu-Zn, magmatic Cu-Ni, epithermal and orogenic Au deposits. However, few attention has been paid to tungsten deposits. Of these, the source and evolution of the mineralising fluids related to the skarn $\mathrm{W}$ deposits are poorly understood. The Heiyanshan W deposit is hosted by metamorphosed clastic and carbonate beds in the Mesoproterozoic Jianshanzi Formation deposited on a continental margin tectonic setting. The Jianshanzi Formation is intruded by biotite monzogranite that yield weighted ${ }^{206} \mathrm{~Pb} /{ }^{238} \mathrm{U}$ age of $326.9 \pm 1.6 \mathrm{Ma}$, which suggest that the Heiyanshan $\mathrm{W}$ deposit was formed in the Carboniferous. The mineralisation is hosted by a prograde hydrothermal altered zone represented by a garnet (-pyroxene) skarn, and retrograde skarn characterised by fine-grained scheelite. The paragenesis of the Heiyanshan mineralisation can be subdivided into prograde skarn stage, retrograde skarn stage, quartz-sulphide stage and quartz-calcite vein stage. The types of fluid inclusions recognised in the various minerals in the deposits are liquid-rich aqueous, vapour-rich aqueous, and daughter mineral-bearing. The homogenisation temperatures of fluid inclusions from the Heiyanshan deposit decrease from $290 \pm 28^{\circ} \mathrm{C}$ in garnet, through $232 \pm 31^{\circ} \mathrm{C}$ in scheelite, to $232 \pm 36^{\circ} \mathrm{C}$ in quartz and $158 \pm 15^{\circ} \mathrm{C}$ in non-mineralised calcite, which is typical of $\mathrm{W}$-bearing skarn deposits worldwide. The $\delta^{18} \mathrm{O}_{\text {water }}$ values from the Heiyanshan deposit range from +4.7 to $+6.6 \%$ in garnet, +1.3 to $+1.9 \%$ o in quartz and -6.1 to $-4.4 \%$ in calcite. We have measured $\delta \mathrm{D}$ in fluid inclusions from different minerals, although these bulk analyses are just a mixture of the different FIA's present in the sample. The $\delta \mathrm{D}$ values of fluid inclusions in garnet, quartz, and calcite are from -121 to $-71 \%$, -84 to $-75 \%$ and -101 to $-82 \%$, respectively, also indicative of deep-sourced magmatic fluids mixed with meteoric water. The decrease in the homogenisation temperatures for the fluid inclusions at the Heiyanshan deposit is accompanied by a 
drop in salinity indicating that tungsten-bearing minerals precipitated during fluid mixing between magmatic fluids and meteoric water. We conclude that eastern Tianshan Terrane contains two pulse of tungsten metallogenic events of Late Carboniferous and Early Triassic.

Keywords: tianshan, heiyanshan, isotopic geochemistry, fluid inclusion, tungsten skarn

\section{INTRODUCTION}

Chinese production of tungsten accounts for over half of the world's supply of the metal. Skarns are one of the most common hosts for the $\mathrm{W}$ representing $71 \%$ of China's production of $\mathrm{W}$ (Chang et al., 2019). Tungsten deposits in China are widely distributed in the South China Block, Kunlun-Qilian-QinlingDabie-Sulu orogens, Sanjiang and Himalaya-Tibetan, and
Central Asian Orogen Belt (CAOB). The Nanling region in central South China Block contains over $73 \%$ of Chinese tungsten resources in an area covering $\sim 6,600 \mathrm{~km}^{2}$ (Mao et al., 2019).

The eastern Tianshan Terrane (ETT) at the southern margin of the $\mathrm{CAOB}$, is a highly prospective region containing several major porphyry $\mathrm{Cu}-\mathrm{Au}-\mathrm{Mo}$, VMS $\mathrm{Cu}-\mathrm{Zn}$ and magmatic $\mathrm{Cu}-\mathrm{Ni}$ deposits, as well as orogenic and epithermal gold deposits (Chen

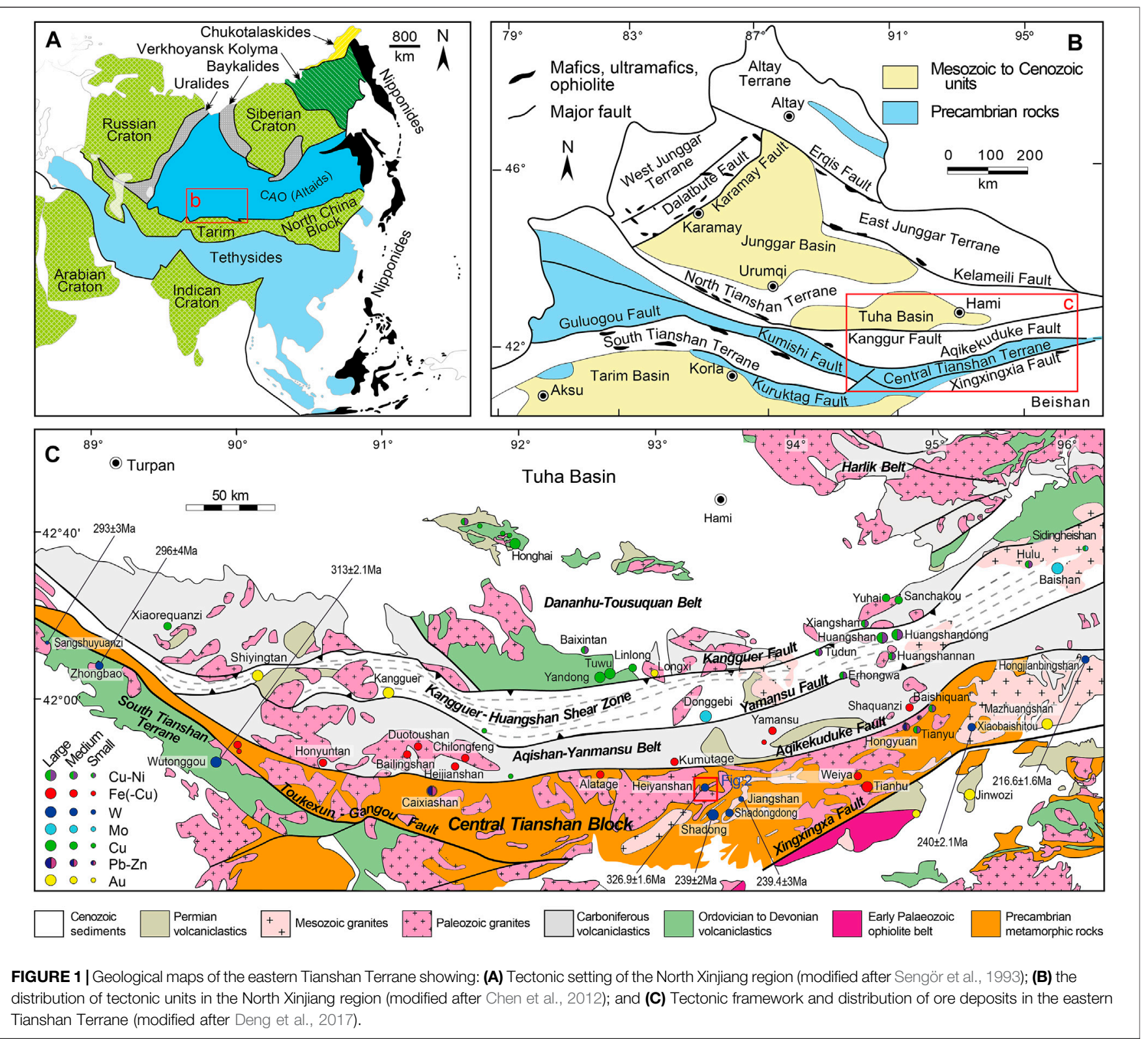


et al., 2012; Deng et al., 2016; Wang et al., 2016, 2018; Wang and Zhang, 2016; Xiao et al., 2017; Wu et al., 2018; Li et al., 2019; Zhang et al., 2019; Chen et al., 2020; He et al., 2020; Muhtar et al., 2020). Several large porphyry Mo and W-(Mo) skarn deposits are also present in the region, including the Donggebi Mo, Baishan Mo, Shadong $\mathrm{W}-\mathrm{Rb}$ and Xiaobaishitou $\mathrm{W}-(\mathrm{Mo})$ deposits (Deng et al., 2017; Wu et al., 2017; Chen et al., 2018; Li et al., 2019b, 2020a). These $\mathrm{W}$ skarn deposits contain resources of over

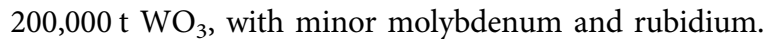

The Heiyanshan $\mathrm{W}$ skarn deposit located in the central part of the ETT was discovered in 2013 with a pre-mining resource of over $10,000 \mathrm{t} \mathrm{WO}_{3}$. Previous studies focused on the geology, geochemistry, geochronology of ore-related granites at $\mathrm{W}$ deposits of the ETT (Chen, 2006; Li et al., 2011; Deng et al., 2017; Chen et al., 2018; Li et al., 2019a), but there are few detailed descriptions of fluid inclusions and systematic isotope studies of the major skarn $\mathrm{W}$ deposits. The Heiyanshan skarn deposits provide an excellent opportunity to study the source and evolution of mineralised fluids and metals, and how the $\mathrm{W}$ mineralisation precipitated in skarns. This study aims to improve our understanding of the major W skarn mineralisation in NW China.

\section{REGIONAL GEOLOGY}

The CAOB is bounded by the Tarim Block to the south and by the Siberian Craton to the north (Figures 1A-C; Sengör et al., 1993; Windley et al., 2007; Xiao et al., 2013, 2020). The ETT is a significant component of the CAOB located between the Kelameli Fault in the north and the Toukexun-Gangou-Xinxingxa Fault in the south (Figure 1B). The ETT is subdivided into the North Tianshan and Central Tianshan Blocks, separated by the Aqikekuduke Fault (Figure 1C; Qin et al., 2002).

The Northern Tianshan Block is subdivided in the DananhuTousuquan and Harlik Belts in the north separated from the Aqishan-Yanmansu Belt in the south by the KangguerHuangshan Shear Zone (Gu et al., 2001). The DananhuTousuquan volcanic arc consists of Ordovician to Devonian volcanic and sedimentary rocks hosting VMS $\mathrm{Cu}-\mathrm{Zn}$ deposits (Deng et al., 2016, 2020) and porphyry Cu deposits (Zhang et al., 2006; Wang et al., 2016, 2018). The Yamansu volcanic arc includes Carboniferous to Permian volcanic-sedimentary rocks hosting several Fe deposits (Zhao et al., 2019). The Kanggur-Huangshan Shear Zone includes $\mathrm{Cu}-\mathrm{Ni}$ sulphide, porphyry Mo deposits and orogenic Au deposits (Mao et al., 2015; Wu et al., 2018; Muhtar et al., 2020).

The Central Tianshan Block (CTB) includes Meso-to Neoproterozoic greenschist to amphibolite facies metamorphic rocks and minor Palaeozoic volcano-sedimentary rocks (Qin et al., 2002; Lei et al., 2011). The Mesoproterozoic rocks include Jianshanzi Formation in the Kawabulag Group (Lei et al., 2011). The Precambrian units are intruded by Palaeozoic and Mesozoic plutons (Wang et al., 2006), some of which are related to tungsten skarn deposits, such as the Xiaobaishitou and Heiyanshan deposits (Deng et al., 2017). The CTB includes the Weiya V-Ti magnetite, Tianhu Fe, and the Caixiashan giant-size $\mathrm{Pb}-\mathrm{Zn}$ deposit, and the Permian maficultramafic complexes present along the northern margin of the area, which hosts the Tianyu and Baishiquan $\mathrm{Cu}-\mathrm{Ni}$ deposits ( $\mathrm{Wu}$ et al., 2010; Yu et al., 2018; Li et al., 2019; Tang et al., 2020).

\section{GEOLOGY OF THE HEIYANSHAN DEPOSIT}

\section{Geological Background}

The host lithologies at Heiyanshan deposit consist of the Mesoproterozoic Jianshanzi Formation of the Kawabulag Group (Figure 2; Hu et al., 2016). The Kawabulag Group is distributed in the southern part of the Heiyanshan district (Figure 2A), with strike near east-west and dip about $50^{\circ}-70^{\circ}$ to the southeast. It is represented by a suite of metamorphic rocks, mainly marble, dolomite marble, metamorphic sandstone, and mica quartz schist, in which marble is the main ore-bearing lithology.

The igneous rocks at the deposit include Carboniferous biotite monzogranite and E-trending dykes of diorite. The Carboniferous biotite monzogranite is distributed in the northern part of the ore district, intruding into the Kawabulag Group. It is grey, medium-grained, and consists of plagioclase (35-40 wt\%), K-feldspar (25-33 wt\%), quartz (25-30 wt\%), biotite (5-8 wt\%), and accessory amounts of tourmaline and zircon. The biotite monzogranite is characterized by high silicon and alkali, and plot into high-K calc-alkaline series. The ASI values cluster between 0.91 and 1.02 , indicating metaluminous affinity. The residual marble of the Kawabulag Group can be seen in the biotite monzogranite, accompanied by scheelite mineralization.

The structure of the ore district includes faults, folds and contact zone structures, which obviously control the formation and distribution of orebodies.

\section{Orebodies}

The Heiyanshan deposit includes 25 scheelite-rich orebodies hosted by skarn in contact of biotite monzogranite and marble, to a minor extent, in fractures in the biotite monzogranite (Jiang, 2016). Three economic W orebodies referred to as the No. XVIII, XX, XIV orebodies grading between 0.12 and $1.06 \mathrm{wt} \% \mathrm{WO}_{3}$ have been delineated at the deposit, which are $100-1,500 \mathrm{~m}$ long and $0.5-8 \mathrm{~m}$ thick (Figure 2A; Hu et al., 2016).

No. XVIII orebody is located in the southwestern part of the ore district, with the thickness of $4.6 \mathrm{~m}$, and length of $1,186 \mathrm{~m}$ and an ore grade of $0.52 \mathrm{wt} \% \mathrm{WO}_{3}$. The orebody is mainly composed of garnet skarn and diopside skarn, which occurs in the external contact skarn zone along the contact zone structure. The direction of dip of the orebody is $120-170^{\circ}$ and the dip angle is $50-90^{\circ}$.

No. XIV orebody is located in the northwest of the ore district, with a thickness of $1.1 \mathrm{~m}$, and a length of $1,194 \mathrm{~m}$ and an ore grade of $0.41 \mathrm{wt} \% \mathrm{WO}_{3}$. The orebody is mainly composed of garnet skarn and diopside skarn and occurs in the external contact skarn zone along the contact zone structure (Figure 3). The direction of dip of the orebody is $350-14^{\circ}$ and the dip angle is $40-65^{\circ}$. 

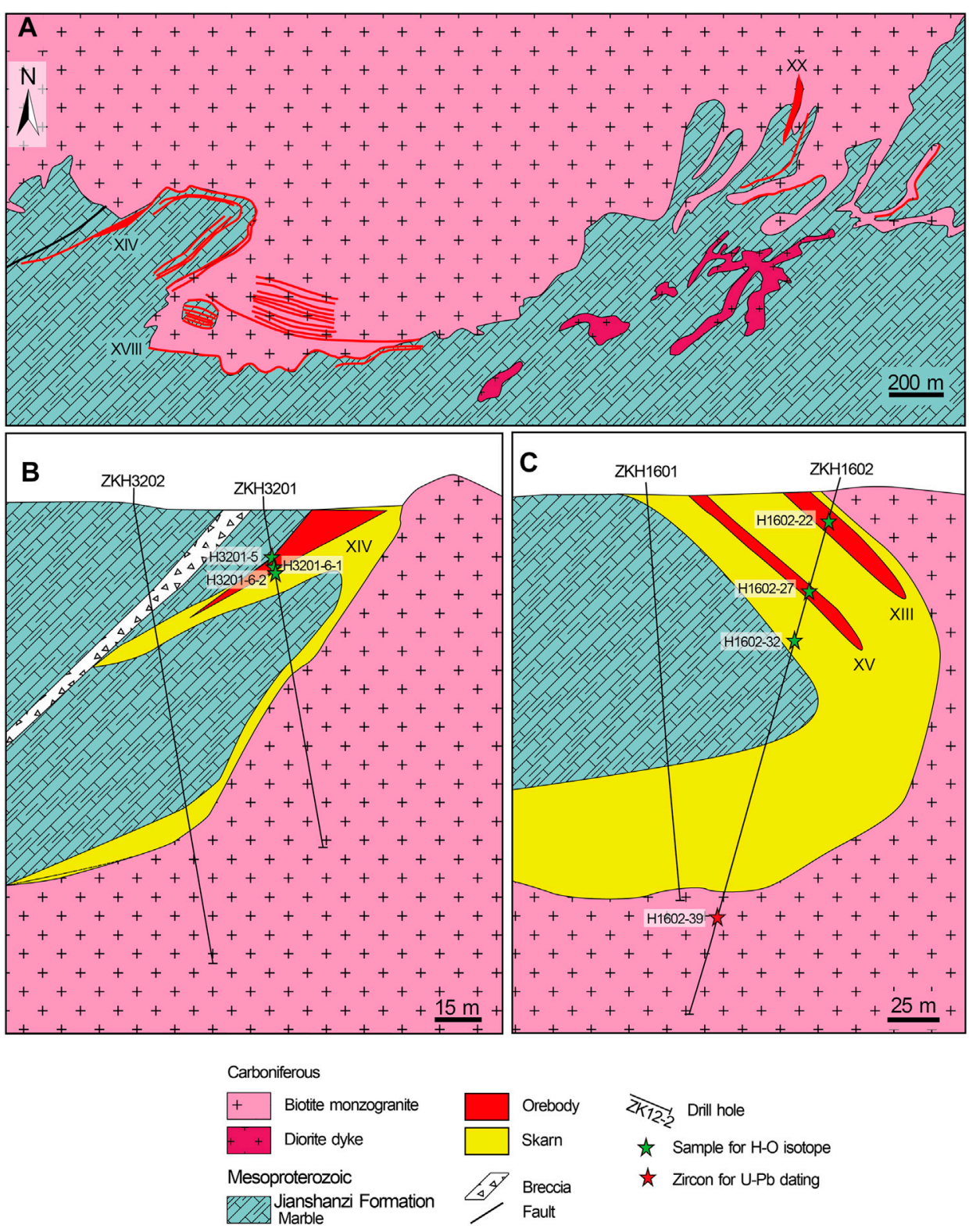

FIGURE 2 | Geological map and profiles of the Heiyanshan deposit (modified after Hu et al., 2016).

No. XX orebody is located in the eastern part of the ore district, with the thickness of $7.2 \mathrm{~m}$, and length of $289 \mathrm{~m}$ and an ore grade of $0.31 \mathrm{wt}$ $\% \mathrm{WO}_{3}$. The orebody occurred as lens between biotite monzogranite and marble, with a dip of $135^{\circ}$ and a dip angle is $50-70^{\circ}$.

\section{Skarn Mineralogy and Paragenesis}

The skarn is zoned with garnet in the inner zone near biotite monzogranite, succeeded by pyroxene in the outer zone (Figure 3). The skarn is composed of garnet and pyroxene, with minor amounts of scheelite, magnetite, quartz, and calcite (Figures $\mathbf{4 A , B}$ ). The scheelite is disseminated in the skarn and associated with the retrograde skarn alteration, or in quartz veins cut the skarn (Figures 4B,C,E). Based on field investigation and petrographic observation, the paragenesis of the Heiyanshan mineralisation is subdivided into: 1) prograde skarn stage; 2) retrograde skarn stage; 3) quartz-sulphide vein stage; and 4) quartz-calcite vein stage (Figure 5).

The prograde skarn stage is characterised by large amounts of garnet and pyroxene in banded skarn (Figures 4A,D). The garnet is fine-grained $(0.05-0.5 \mathrm{~mm})$, euhedral to subhedral, and is commonly intergrown with pyroxene (Figures 4D,E,G). The EPMA data show that garnet from the Heiyanshan $\mathrm{W}$ deposit is essentially grossulariteandradite-pyralspite (Gr-Ad-Py) solid solutions (Table 1; Figure 6A). The composition of garnet is relatively uniform and there are no obvious core and rim structure. In most cases, the garnet are enriched in Fe relative to $\mathrm{Al}$. The composition range of $\mathrm{Gr}$, Ad and 


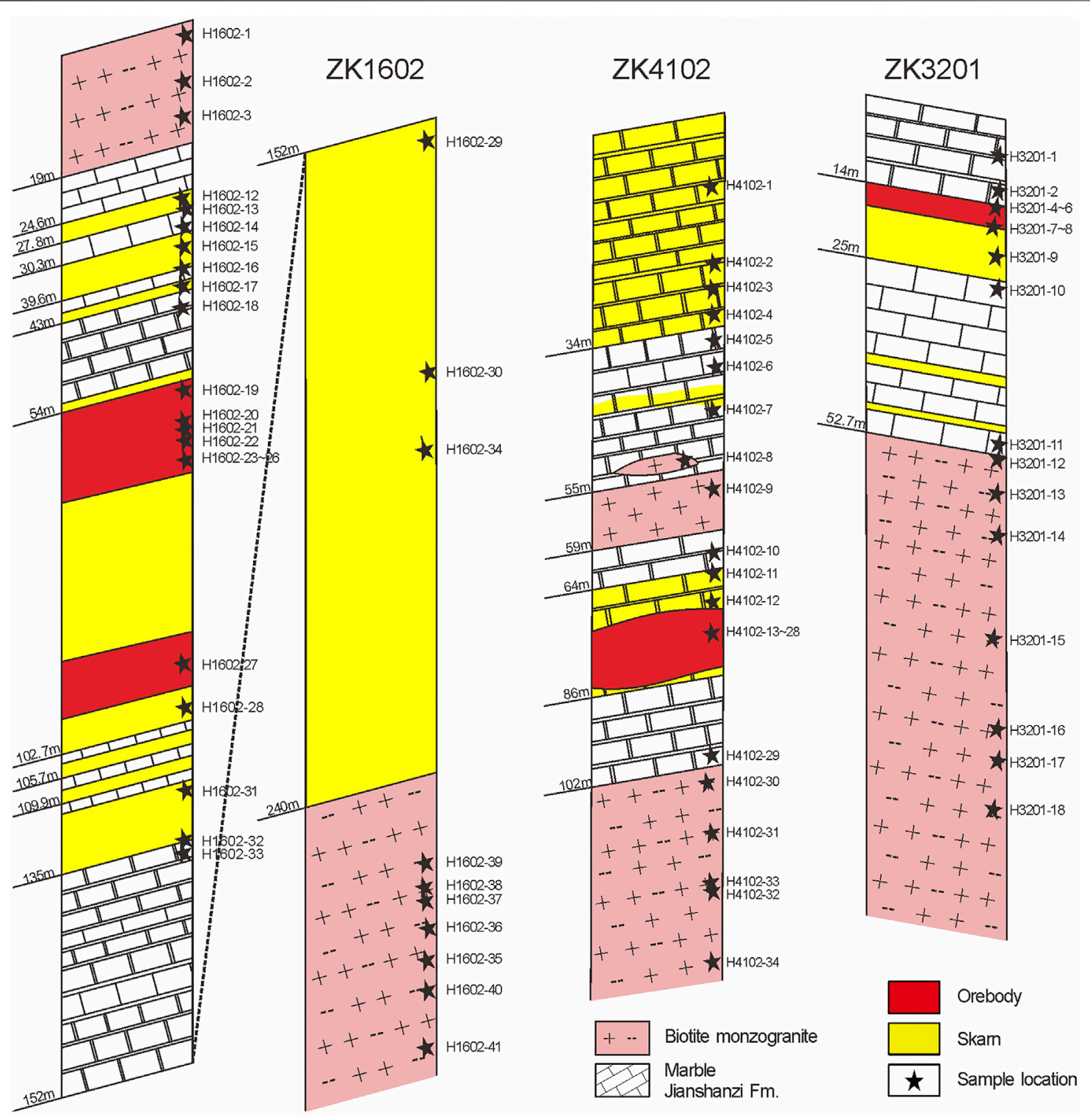

FIGURE 3 | Columnar diagram of drill hole of the Heiyanshan deposit showing the sample location.

Py is $78.43-80.39 \%, 8.99-11.58 \%$, and $9.99-11.47 \%$, respectively. The pyroxene is green, fine-grained $(0.01-0.5 \mathrm{~mm})$, and euhedral to subhedral (Figure 4H). The EPMA data show that pyroxene from the Heiyanshan $\mathrm{W}$ deposit is essentially diopside-hedenbergite (DiHd) solid solutions (Table 1; Figure 6B). In summary, the garnet in the Heiyanshan $\mathrm{W}$ deposit displays characteristics similar to those in most other skarn systemsand are compositionally consistent with garnets in W skarns (Figure 6; Meinert et al., 2005).

The retrograde skarn stage consists of epidote, tremolite, actinolite, scheelite and quartz, which replace the garnet and pyroxene in the prograde skarn (Figures 4B,G). The quartzsulphide stage is characterised by veins with the mineral assemblages of quartz-scheelite, and quartz-molybdenitepyrrhotite-chalcopyrite-sphalerite-galena, which cross-cut the earlier stages intrude into the earlier skarn stage ores (Figures
4C,E,F). The quartz-calcite stage is represented by calcite veinlets crosscutting the skarn (Figure 4I). In addition, the tourmaline occurs as veins in altered granite (Figures $\mathbf{4 C}, \mathbf{J}$ ) and has no direct contact with skarn minerals, thus, the relationship between tourmaline and skarn is not clear. However, tourmaline is replaced by quartz + calcite (Figure 4J), indicating earlier than the quartz-calcite stage.

\section{SAMPLING AND ANALYTICAL METHODS}

\section{Fluid Inclusion Study}

All the samples used for fluid inclusions study were collected from drill hole of the Heiyanshan deposit (Figure 3). Doubly polished thin sections with a thickness of $\sim 0.20 \mathrm{~mm}$ were 

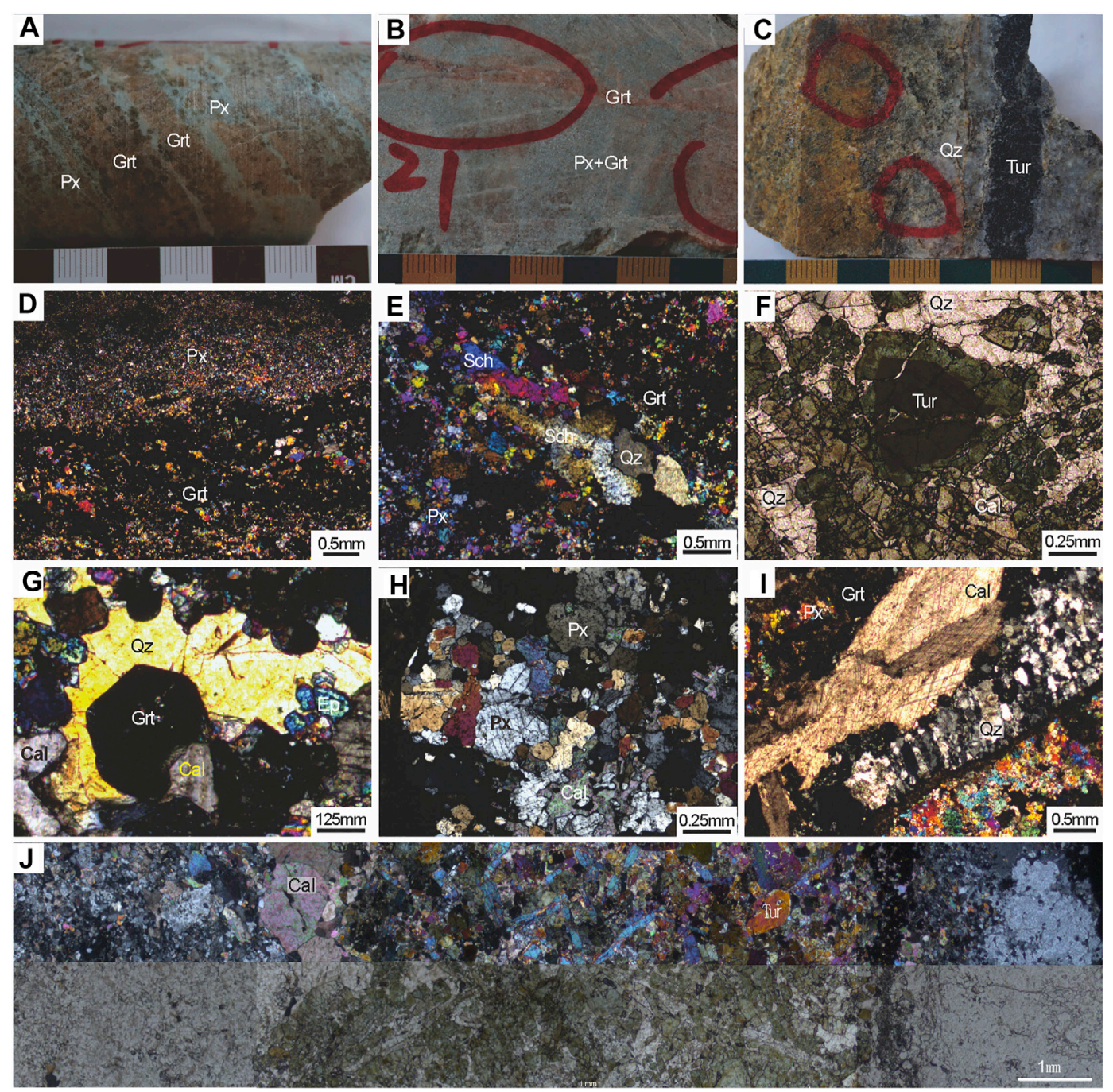

FIGURE 4 | Photographs and photomicrographs of mineralisation at the Heiyanshan deposit: (A) garnet and pyroxene in banded skarn; (B) disseminated scheelite in the garnet-pyroxene skarn; (C) tourmaline occurred as vein in altered biotite monzogranite; (D) garnet and pyroxene in banded skarn; (E) quartz-scheelite vein crosscut the garnet-pyroxene skarn; (F) tourmaline in altered monzogranite; (G) prograde euhedral garnet overgrown by retrograde epidote, quartz, and calcite; (H) prograde pyroxene replaced by calcite; and (I) prograde garnet and pyroxene cut by a quartz-calcite vein. (J) tourmaline occurs as veins in altered granite, and replaced by quartz + calcite.

prepared from garnet, scheelite, quartz, and calcite samples associated with different stages of the Heiyanshan mineralisation. The fluid inclusions were carefully observed to identify their genetic relationships and types, vapour-liquid ratios, and spatial clustering, and to choose representative examples for microthermometric studies. The studies were carried out using a Linkam THMSG600 Heating-Freezing stage at the Fluid inclusion laboratory of the Institute of Geology for Mineral Resources in Beijing. The heating stage is designed to measure temperatures between -196 and $600^{\circ} \mathrm{C}$, and it was attached to a Leica DM2700P microscope connected to a television camera and screen. The stage was calibrated using synthetic fluid inclusions at $-56.6,0.0$, and $+374.1^{\circ} \mathrm{C}$, with a heating/freezing rate of $0.2-5.0^{\circ} \mathrm{C} / \mathrm{min}$, which was reduced to $<0.2^{\circ} \mathrm{C} / \mathrm{min}$ near the phase transformation. The uncertainties for the measurements are $\pm 0.5^{\circ} \mathrm{C}$ for runs in the range from -120 to $30^{\circ} \mathrm{C}, \pm 1$ for temperatures between 30 and $300^{\circ} \mathrm{C}$, and $\pm 2.0^{\circ} \mathrm{C}$ from 300 to $600^{\circ} \mathrm{C}$. Ice melting temperatures were observed at a heating rate of less than $0.1^{\circ} \mathrm{C} / \mathrm{min}$, and homogenisation temperatures at a rate of $\leq 1^{\circ} \mathrm{C} / \mathrm{min}$.

All low-temperature phase transitions were measured using a standard procedure starting with rapidly cooling to $-120^{\circ} \mathrm{C}$. This was followed by progressive heating at a rate of $5-10^{\circ} \mathrm{C} / \mathrm{min}$ and reduced to $<0.5^{\circ} \mathrm{C} / \mathrm{min}$ near the phase transformation. Twophase transitions were observed in the inclusions involving the melting of the ice $\left(T \mathrm{~m}_{\text {(ice) }}\right)$ and the homogenisation temperature (Th). All the phase transitions were measured using the cycling method described by Goldstein and Reynolds (1994). Salinities of aqueous inclusions were calculated using the equations of Bodnar (1993). 


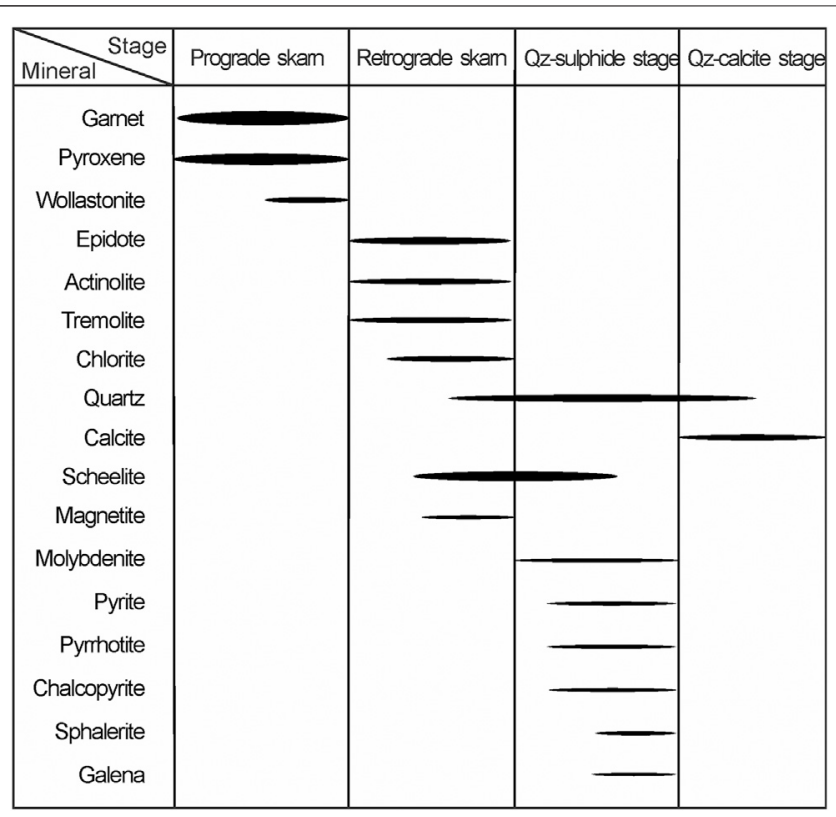

FIGURE 5 | Mineral paragenesis for the Heiyanshan W deposit.

\section{Isotopic Analyses}

Ten samples from the Heiyanshan deposit were selected for hydrogen and oxygen isotope studies. The sample location is recorded in Figure 2 and Figure 3. The samples from the Heiyanshan deposit comprise four from garnet in the prograde skarn, three from quartz in the quartz-sulphide stage, and three from calcite in the carbonate stage.

The analytical methods were explained in detail by Ding (1988). Mineral separates were reacted with $\mathrm{BrF}_{5}$, followed by total conversion to $\mathrm{CO}_{2}$ for oxygen isotope analysis. The $\delta \mathrm{D}$ values were measured on water in fluid inclusions decrepitated from garnet, quartz, and calcite separates by heating at $600^{\circ} \mathrm{C}$ for $1 \mathrm{~h}$. The released gases were passed through a $\mathrm{CuO}$ bucket at $600^{\circ} \mathrm{C}$ and frozen with liquid nitrogen to obtain water from which hydrogen gas was released by reduction with zinc.

The oxygen, hydrogen and carbon isotope analyses were conducted using a Finnigan MAT 253 EM mass spectrometer at the Open Laboratory for Isotope Geochemistry, Chinese Academy of Geological Sciences in Beijing. Isotopic data were reported per mil relative to the Vienna SMOW standard for oxygen and hydrogen. The total uncertainties were estimated to be better than $\pm 0.2 \%$ for $\delta^{18} \mathrm{O}$ and $\pm 2.0 \%$ for $\delta \mathrm{D}$ at the $\sigma$ level.

\section{Zircon LA-ICPMS U-Pb Dating}

Zircon sample was collected from unaltered granite (H1602-39). The sample location is recorded in Figure 2C and Figure 3. The $\mathrm{LA}-\mathrm{ICP}-\mathrm{MS} \mathrm{U}-\mathrm{Pb}$ dating analyses of zircon was performed at the Key Laboratory of Marine Resources and Coastal Engineering, Sun Yat-sen University. The analyses were performed using a $193 \mathrm{~nm}$ ArF excimer laser ablation system (GeoLasPro) coupled with an Agilent 7,700x ICP-MS. A $32 \mu \mathrm{m}$ spot size was used with an energy density of $5 \mathrm{~J} / \mathrm{cm}^{2}$ and a repetition rate of $5 \mathrm{~Hz}$. Zircon 91500 was used as age standard (1,062 Ma, Wiedenbeck et al., 1995). Analytical methodology is described in detail in Liu et al. (2010). Errors on individual analyses by LA-ICPMS are quoted at 95\% $(1 \sigma)$ confidence level.

\section{FLUID INCLUSIONS}

\section{Types of Fluid Inclusions}

Three types of primary fluid inclusions were identified in different minerals from the Heiyanshan deposits (Figure 7). The L-type inclusions are biphase liquid-rich inclusions with variable proportions of vapour between 5 and 20 vol\%. This type of inclusion commonly has a negative crystal shape, elliptic or irregular shapes and range in size from 5 to $20 \mu \mathrm{m}$, and is the dominant type at the Heiyanshan deposits (about 90\% of the total). The V-type inclusions are biphase inclusions with high vapour proportions containing $>50 \%$ vapour/(vapour + liquid).

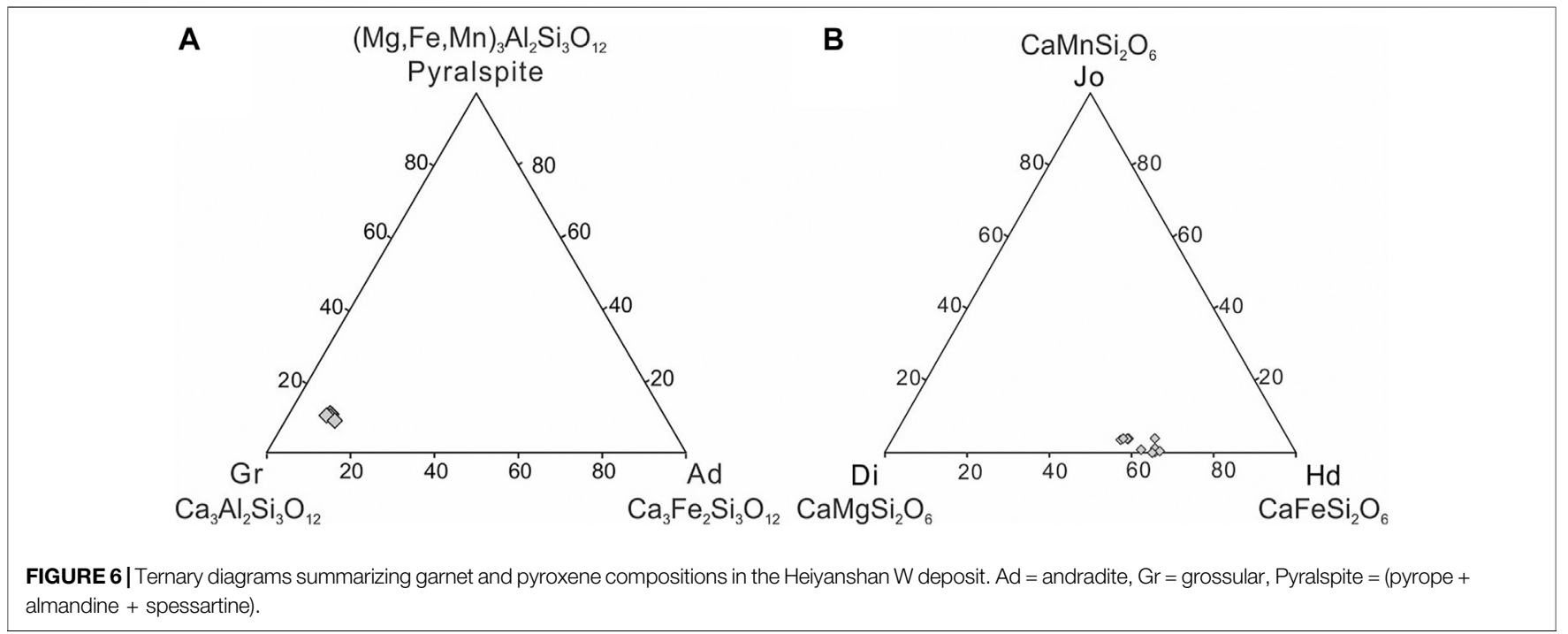


TABLE 1 | Representative Electron Microprobe Analyses of garnet from the Heiyanshan deposit.

\begin{tabular}{|c|c|c|c|c|c|}
\hline Sample no & h1602-21-1.1 & h1602-21-1.2 & h1602-21-2.1 & h1602-21-2.2 & h1602-21-2.3 \\
\hline \multicolumn{6}{|c|}{ Oxide composition (wt\%) } \\
\hline $\mathrm{SiO}_{2}$ & 39.75 & 39.69 & 40.17 & 40.03 & 39.57 \\
\hline $\mathrm{TiO}_{2}$ & 0.26 & 0.30 & 0.11 & 0.23 & 0.42 \\
\hline $\mathrm{Al}_{2} \mathrm{O}_{3}$ & 20.52 & 20.49 & 20.68 & 20.85 & 20.24 \\
\hline $\mathrm{Cr}_{2} \mathrm{O}_{3}$ & 0.01 & 0.00 & 0.00 & 0.02 & 0.01 \\
\hline $\mathrm{TFe}^{\mathrm{a}}$ & 5.83 & 5.90 & 5.73 & 5.38 & 6.06 \\
\hline $\mathrm{MnO}$ & 2.44 & 2.33 & 2.35 & 2.47 & 2.36 \\
\hline $\mathrm{MgO}$ & 0.11 & 0.09 & 0.10 & 0.08 & 0.06 \\
\hline $\mathrm{CaO}$ & 33.5 & 33.17 & 33.91 & 33.83 & 34.02 \\
\hline Total & 102.42 & 101.97 & 103.05 & 102.89 & 102.74 \\
\hline \multicolumn{6}{|c|}{ Number of ions on the base of 12 atoms of oxygen and $0 \mathrm{OH}$} \\
\hline $\mathrm{Si}$ & 2.972 & 2.978 & 2.982 & 2.975 & 2.954 \\
\hline $\mathrm{Ti}$ & 0.015 & 0.017 & 0.006 & 0.013 & 0.024 \\
\hline $\mathrm{Al}$ & 1.808 & 1.812 & 1.809 & 1.826 & 1.781 \\
\hline $\mathrm{Cr}^{3+}$ & 0.001 & 0.000 & 0.000 & 0.001 & 0.001 \\
\hline $\mathrm{Fe}^{3+}$ & 0.201 & 0.191 & 0.199 & 0.181 & 0.233 \\
\hline $\mathrm{Fe}^{2+}$ & 0.164 & 0.179 & 0.157 & 0.154 & 0.145 \\
\hline $\mathrm{Mn}^{2+}$ & 0.155 & 0.148 & 0.148 & 0.155 & 0.149 \\
\hline $\mathrm{Mg}^{2+}$ & 0.012 & 0.010 & 0.011 & 0.009 & 0.007 \\
\hline $\mathrm{Ca}^{2+}$ & 2.683 & 2.667 & 2.697 & 2.694 & 2.721 \\
\hline Total cations & 8.011 & 8.002 & 8.009 & 8.008 & 8.015 \\
\hline \multicolumn{6}{|c|}{ End member percentages } \\
\hline Grossularite & 79.01 & 79.24 & 79.62 & 80.39 & 78.43 \\
\hline Andradite & 9.990 & 9.530 & 9.910 & 8.990 & 11.58 \\
\hline $\mathrm{Pyr}+\mathrm{Spe}+\mathrm{Alm}$ & 11.00 & 11.23 & 10.47 & 10.62 & 9.990 \\
\hline
\end{tabular}

Abbreviation: Alm = alamadine, $P y r=$ pyrope, $S p=$ Spessartine.

$\mathrm{TFe}^{\mathrm{a}}=\mathrm{FeO}+\mathrm{Fe}_{2} \mathrm{O}_{3}$.

TABLE 2 | Microthermometric data for fluid inclusions from the Heiyanshan W deposits.

\begin{tabular}{|c|c|c|c|c|c|c|c|c|}
\hline \multirow[t]{2}{*}{ Mineral } & \multirow[t]{2}{*}{ Type } & \multirow[t]{2}{*}{$T_{\text {m(ice) }}$ (No.) } & \multicolumn{2}{|c|}{$T_{\mathrm{h}}\left({ }^{\circ} \mathrm{C}\right)$} & \multicolumn{2}{|c|}{$W$ (wt\% $\mathrm{NaCl}$ equiv.) } & \multicolumn{2}{|c|}{$\rho\left(\mathrm{g} / \mathrm{cm}^{3}\right)$} \\
\hline & & & Range (No.) & Mean & Range & Mean & Range & Mean \\
\hline Garnet & $\mathrm{L}$ & -9.4 to $-4.8(33)$ & 228-338 (33) & $290 \pm 28$ & $7.6-13.3$ & $10.4 \pm 1.6$ & $0.7-0.9$ & $0.83 \pm 0.04$ \\
\hline Scheelite & $L$ & -9.5 to $-3.4(28)$ & 146-296 (28) & $232 \pm 31$ & $5.6-13.4$ & $9.4 \pm 1.9$ & $0.8-1.0$ & $0.90 \pm 0.04$ \\
\hline Quartz & $L$ & -9.5 to $-3.2(159)$ & 178-393 (159) & $232 \pm 36$ & $5.3-13.4$ & $9.0 \pm 1.7$ & $0.8-1.0$ & $0.89 \pm 0.03$ \\
\hline Calcite & $\mathrm{L}$ & -5.5 to $-1.6(35)$ & 136-186 (35) & $158 \pm 15$ & $2.7-8.5$ & $5.2 \pm 1.3$ & $0.9-1.0$ & $0.95 \pm 0.02$ \\
\hline
\end{tabular}

These inclusions commonly have negative crystal or ellipse shape and range in size from 5 to $30 \mu \mathrm{m}$.

\section{Entrapment Sequence of Fluid Inclusions}

The Microthermometry results of fluid inclusions in the samples of the Heiyanshan W deposit are summarized in Figure 8. Although CL image can be successfully used for the interpretation of the entrapment sequence of fluid inclusions in the sample, the entrapment sequence of fluid inclusions was identified in the different skarn minerals. The prograde skarn stage includes garnet and pyroxene, which contain abundant L-type inclusions (Figure 7A) and are considered to be primary fluid inclusions (c.f. Goldstein and Reynolds, 1994; Chi et al., 2021). The retrograde skarn stage contains scheelite, which contain primary L-type and V-type inclusions that are scattered or randomly distributed within the host crystals (Figure 7B). The sulphide stage includes sulphide and quartz enriched in L- and V-type inclusions (Figures 7C-E). The carbonate stage contains L-type fluid inclusions in calcite (Figure 7F).

\section{Microthermometry}

In the prograde garnet, 33 of L-type and inclusions have been analyzed (Table 2; Figure 8). The L-type inclusions with melting of the ice $\left(T_{\mathrm{m} \text { (ice) }}\right)$ range from -9.4 to $-4.8^{\circ} \mathrm{C}$, corresponding to salinity of $7.6-13.3 \mathrm{wt} \% \mathrm{NaCl}$ equiv (mean $=10.4 \pm 1.6 \mathrm{wt} \% \mathrm{NaCl}$ equiv.). They are homogenized to liquid at $228-338^{\circ} \mathrm{C}$, with mean of $290 \pm 28^{\circ} \mathrm{C}$. The bulk densities range from 0.74 to $0.93 \mathrm{~g} / \mathrm{cm}^{3}$.

In the scheelite of quartz-sulfide stage, $28 \mathrm{~L}$-type inclusions have been analyzed (Table 2). The L-type inclusions with $T_{\mathrm{m} \text { (ice) }}$ range from -9.5 to $-3.4^{\circ} \mathrm{C}$. The estimated salinities range from 5.6 to $13.4 \mathrm{wt}$ $\% \mathrm{NaCl}$ equiv (mean $9.4 \pm 1.9 \mathrm{wt} \% \mathrm{NaCl}$ equiv.). They are homogenized to liquid at temperatures of $146-296^{\circ} \mathrm{C}$ (mean = $232 \pm 31^{\circ} \mathrm{C}$ ), slightly lower than that of the L-type inclusions in prograde garnet. The bulk densities range from 0.81 to $0.96 \mathrm{~g} / \mathrm{cm}^{3}$. 


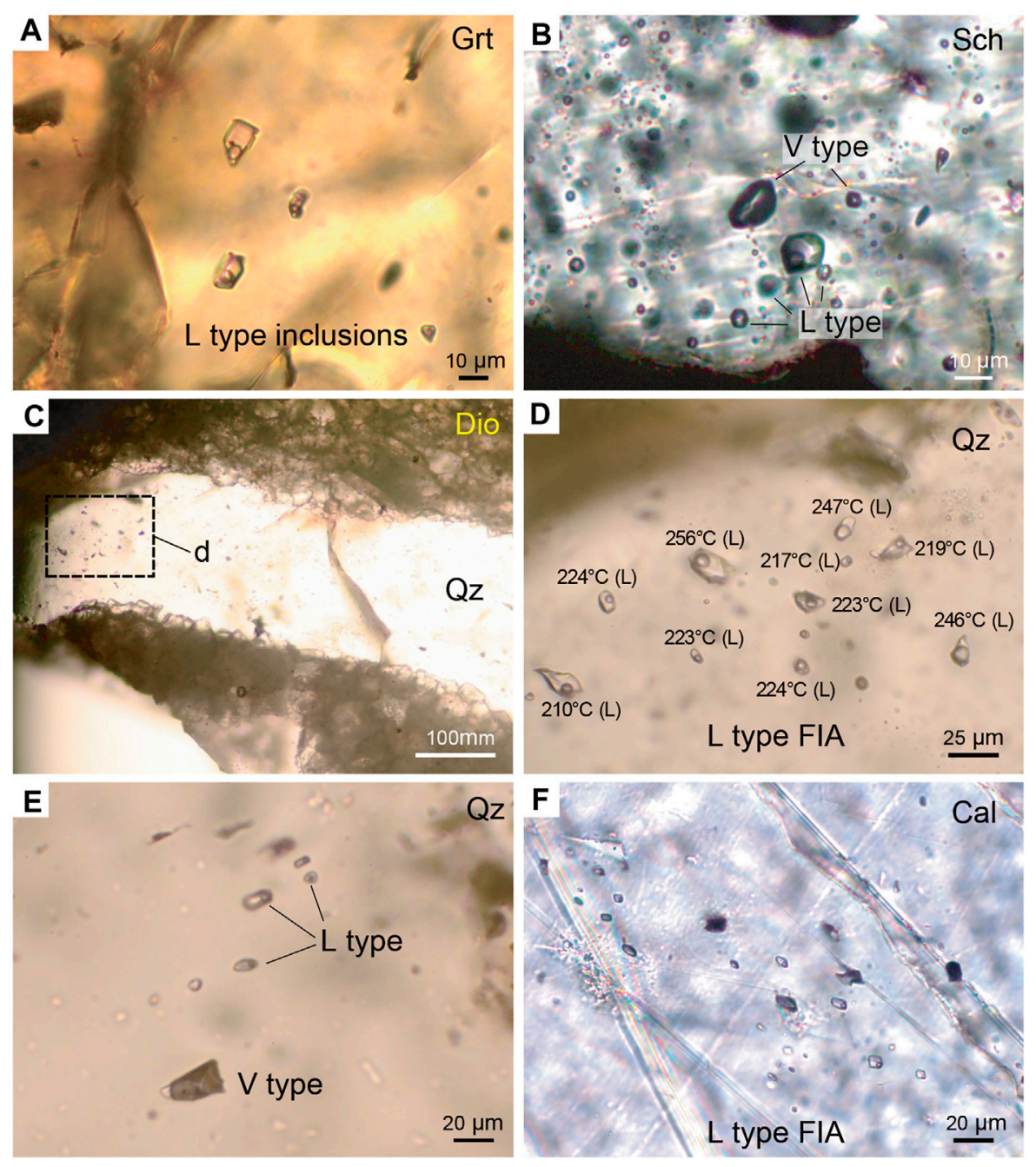

FIGURE 7 | Photomicrographs of fluid inclusions from the Heiyanshan deposit showing: (A) scattered two-phase L-type fluid inclusions in garnet from the prograde skarn; (B) coexistence of L- and V-type fluid inclusions in scheelite (C, D) two-phase L-type fluid inclusions randomly distributed in quartz with similar homogenise temperatures; (E) coexisting L- and V-type fluid inclusions in quartz; and (F) clusters of two-phase L-type fluid inclusions in calcite.

In the quartz of quartz-sulfide stage, 159 L-type inclusions are analyzed (Table 2). The L-type inclusions with $T_{\mathrm{m} \text { (ice) }}$ range from -9.5 to $-3.2^{\circ} \mathrm{C}$. The estimated salinities range from 5.3 to $13.4 \mathrm{wt} \% \mathrm{NaCl}$ equiv (mean $=9.0 \pm 1.7 \mathrm{wt} \% \mathrm{NaCl}$ equiv.). They are homogenized to liquid at temperatures of $178-393^{\circ} \mathrm{C}\left(\right.$ mean $\left.=232 \pm 36^{\circ} \mathrm{C}\right)$. The bulk densities range from 0.78 to $0.96 \mathrm{~g} / \mathrm{cm}^{3}$.

In the calcite of carbonate stage, a total of $35 \mathrm{~L}$-type inclusions yield $T_{\mathrm{m} \text { (ice) }}$ of -5.5 to $-1.6^{\circ} \mathrm{C}$ (Table 2), salinities of $2.7-8.5 \mathrm{wt} \%$ $\mathrm{NaCl}$ equiv (mean $=5.2 \pm 1.3 \mathrm{wt} \% \mathrm{NaCl}$ equiv.), and homogenization to liquid at temperature of $136-186^{\circ} \mathrm{C}$ (mean = $158 \pm 15^{\circ} \mathrm{C}$ ). The bulk densities range from 0.91 to $0.98 \mathrm{~g} / \mathrm{cm}^{3}$.

\section{OXYGEN AND HYDROGEN ISOTOPIC SYSTEMATICS}

The $\delta^{18} \mathrm{O}$ values for garnet in the prograde skarn at the Heiyanshan $\mathrm{W}$ deposit range from +4.8 to $+6.7 \%$, and the $\delta^{18} \mathrm{O}$ values for quartz from the sulphide stage range from +11.1 to $+11.7 \%$ (Table 3 ). The $\delta^{18} \mathrm{O}$ values of +8.7 to $+10.4 \%$ for calcite from the carbonate stage are similar to those of the sulphide stage. Considering the homogenisation temperatures of the fluid inclusions, the calculated $\delta^{18} \mathrm{O}_{\text {water }}$ values of the mineralising fluid related to the prograde skarn range from +4.7 to $+6.6 \%$ o (Table 3; Figure 9). The calculated $\delta^{18} \mathrm{O}_{\text {water }}$ values for quartz from the sulphide stage are between +1.3 and $+1.9 \%$, which are obviously lower than those of the skarn. The carbonate stage has $\delta^{18} \mathrm{O}_{\text {water }}$ values between -6.1 and $-4.4 \%$, lower than those of the sulphide stage and skarn.

The measured $\delta \mathrm{D}$ values of fluids associated with the prograde skarn at the Heiyanshan $\mathrm{W}$ deposit are between -121 and $-71 \%$, and the $\delta \mathrm{D}$ values of quartz from sulphide stage range from -84 to $-75 \%$ (Table 3 ). The carbonate stage has $\delta D_{\text {water }}$ values between -101 and $-82 \%$, with are lower than those for the sulphide stage and skarn. 
TABLE 3 | Isotopic compositions (\%o) of samples from the Heiyanshan W deposit.

\begin{tabular}{|c|c|c|c|c|c|}
\hline Samples & Mineral/Rock & $\delta^{18} O_{\text {mineral }}$ & $\mathbf{T}\left({ }^{\circ} \mathrm{C}\right)$ & $\delta^{18} O_{\text {water }}$ & $\delta D_{\text {water }}$ \\
\hline H1602-27 & Garnet & 4.8 & 290 & 4.7 & -83 \\
\hline H1602-32 & Garnet & 5.4 & 290 & 5.3 & -71 \\
\hline H4102-25 & Garnet & 6.6 & 290 & 6.5 & -121 \\
\hline H4102-28 & Garnet & 6.7 & 290 & 6.6 & -119 \\
\hline Average & $N=4$ & 5.9 & 290 & 5.7 & -99 \\
\hline Median & & 6 & 290 & 5.9 & -101 \\
\hline H3201-5 & Quartz & 11.1 & 232 & 1.3 & -84 \\
\hline Н3201-6-1 & Quartz & 11.1 & 232 & 1.3 & -82 \\
\hline H3201-6-2 & Quartz & 11.7 & 232 & 1.9 & -75 \\
\hline Average & $N=8$ & 11.3 & 232 & 1.5 & -80 \\
\hline Median & & 11.1 & 232 & 1.3 & -82 \\
\hline H1602-22 & Calcite & 10.4 & 158 & -4.4 & -96 \\
\hline H1602-27 & Calcite & 8.7 & 158 & -6.1 & -101 \\
\hline H1602-32 & Calcite & 9.7 & 158 & -5.1 & -82 \\
\hline Average & $N=3$ & 9.6 & 158 & -5.2 & -93 \\
\hline Median & & 9.7 & 158 & -5.1 & -96 \\
\hline
\end{tabular}

The $\delta^{18} O_{\text {wtaer }}$ values were calculated using equations for garnet-water, quartz-water and calcite-water provided by Bottinga and Javoy, 1975, Zheng, 1993, and O'Neil et al. (1969), respectively.
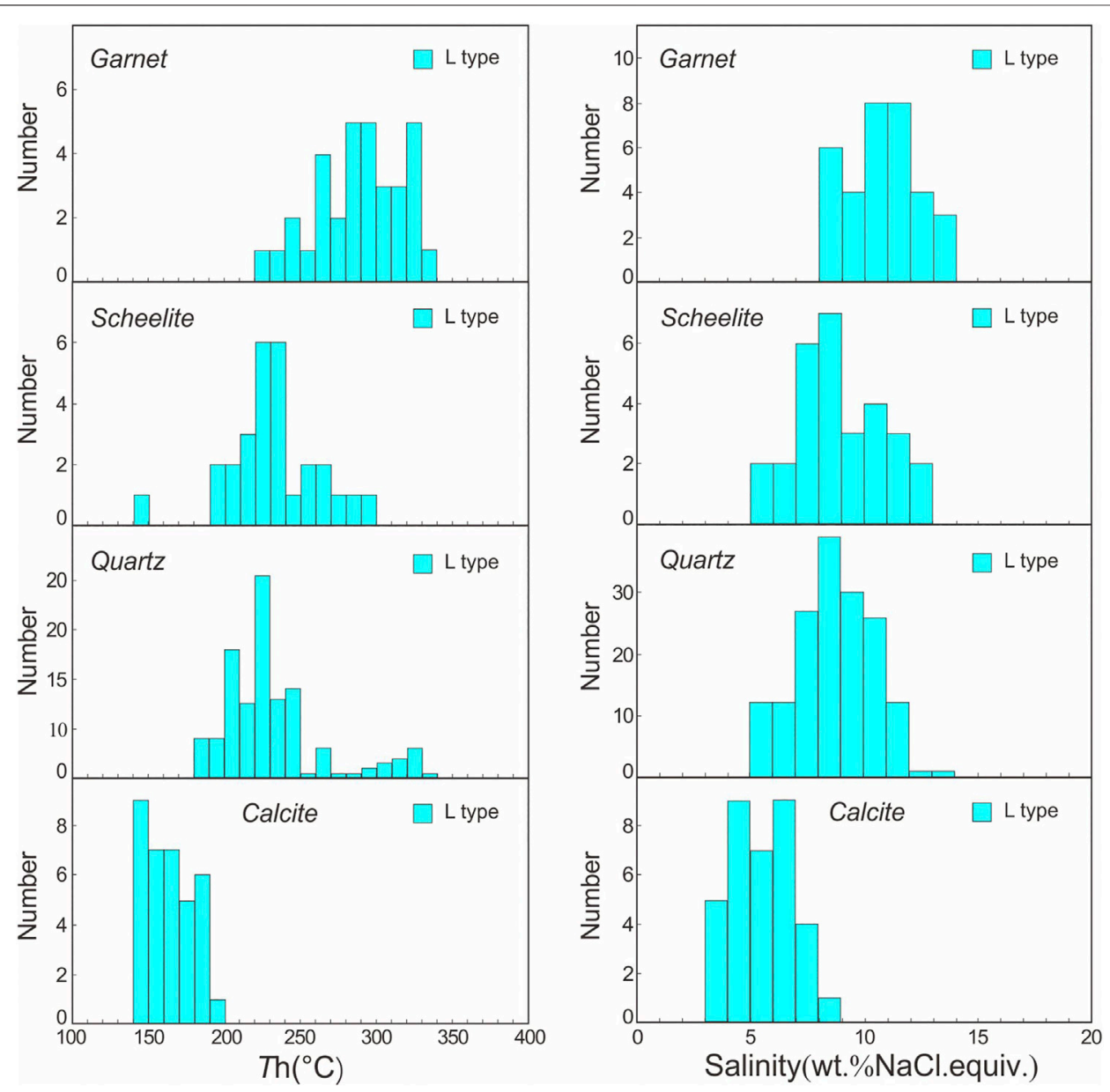

FIGURE 8 | Histogram of the homogenisation temperature and salinity for fluid inclusions at Heiyanshan deposit. 


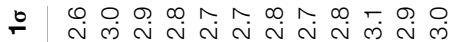

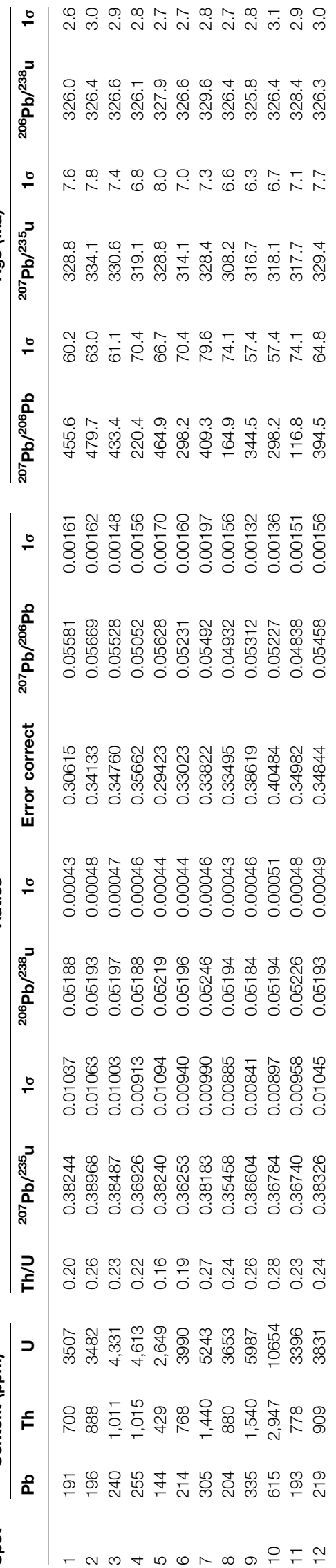

\section{ZIRCON U-PB DATING}

Zircons in sample H1602-39 are colorless and euhedral (Figure 10A). The crystals range in length from 100 to $200 \mu \mathrm{m}$, with length/width ratios ranging from 2:1 to 4:1. Cathodoluminescence images reveal complex zoning characterized by two major concentric zones, i.e., core and rim (Figure 10A). The LA-ICP-MS analyses were concentrated on the zircon rims in an attempt to date the crystallization age of the granite.

Twelve analyses conducted on the rims show they have 2,649-10654 ppm U, 429-2,947 ppm Th, and Th/U ratios of $0.16-0.28$ (Table 4). Their ${ }^{206} \mathrm{~Pb} /{ }^{238} \mathrm{U}$ ages vary from $325.8 \pm$ $2.8 \mathrm{Ma}$ to $329.6 \pm 2.8 \mathrm{Ma}$ ( $1 \sigma$ error), with an average of $326.9 \pm 1.6 \mathrm{Ma}(\mathrm{n}=12, \mathrm{MSWD}=0.16$; Figure $10 \mathrm{~B})$, which is interpreted as the crystallization age of the granite.

\section{DISCUSSION}

\section{Fluid Evolution in the W-Skarn Deposits}

Our studies show that the evolution of hydrothermal fluids related to the Heiyanshan W-skarn deposits involved at least four stages: 1) an early high to moderate temperature of $\sim 290^{\circ} \mathrm{C}$ during the development of the prograde stage; 2 ) development of a retrograde skarn hosting $\mathrm{W}$ mineralisation; 3 ) development of a low-temperature $\left(\sim 230^{\circ} \mathrm{C}\right)$ quartz-sulphide stage hosting scheelite; and 4) development of a low-temperature $\left(160^{\circ} \mathrm{C}\right)$ barren carbonate stage. The temperature of the mineralising fluid decreased from the prograde skarn, through the sulphide stage to the carbonate stage, which is consistent with $\mathrm{W}$-skarns worldwide (Figure 11; Pan et al., 2019).

During Carboniferous, the carbonaceous limestone and marble in the Jianshanzi Formation was intruded by the biotite monzogranite in the extensional event associated with the alteration of the limestone into the prograde skarn. Primary fluid inclusions in minerals have long been thought to be relics or residuals of mineralising fluids trapped and preserved in crystals (c.f. Roedder, 1984; Chen et al., 2007; Pirajno, 2009). For example, prograde skarns at the $\mathrm{W}$-skarn deposits in the Tienshan region included high temperature $\left(>400^{\circ} \mathrm{C}\right)$, medium pressure (>700 bars), and high salinity ( $>45 \mathrm{wt} \% \mathrm{NaCl}$ equiv.) magmatic-related hydrothermal fluids that exsolved from a crystallising magma (Soloviev, 2011, 2015; Soloviev and Kryazhev, 2017a,b). However, the fluid inclusions at the W-hosted prograde skarns in the ETT have high to moderate homogenisation temperatures of $\sim 300^{\circ} \mathrm{C}$ and medium to low salinities and are classified as $\mathrm{NaCl}-\mathrm{H}_{2} \mathrm{O}$ fluids. Furthermore, the tourmaline occurs as veins in altered granite indicates that the magma-related hydrothermal fluid at the deposits contained boron in addition to aqueous solution (Figure 4F).

The fluid inclusions in the retrograde skarn at the Heiyanshan $\mathrm{W}$ deposit are characterised by their low temperatures $\left(\sim 230^{\circ} \mathrm{C}\right)$, moderate to low salinities, and can be classified as a $\mathrm{NaCl}-\mathrm{H}_{2} \mathrm{O}$ fluid. The $\mathrm{H}-\mathrm{O}$ isotopes in the quartz at the deposit are indicative of magmatic fluids mixed with meteoric water resulted in the formation of coarse-grained scheelite in quartz veins. 

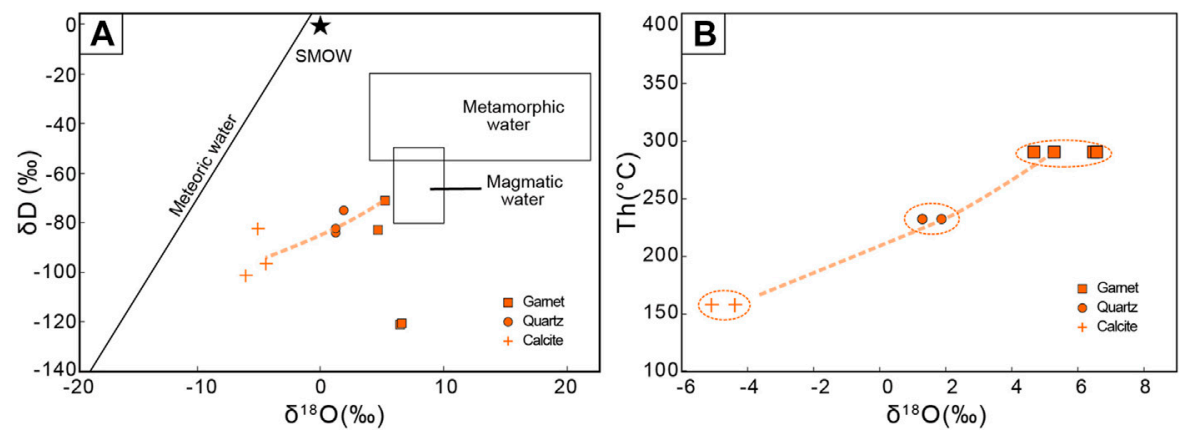

FIGURE 9 | CL images and concordia diagrams of zircon samples from the Heiyanshan W deposit.
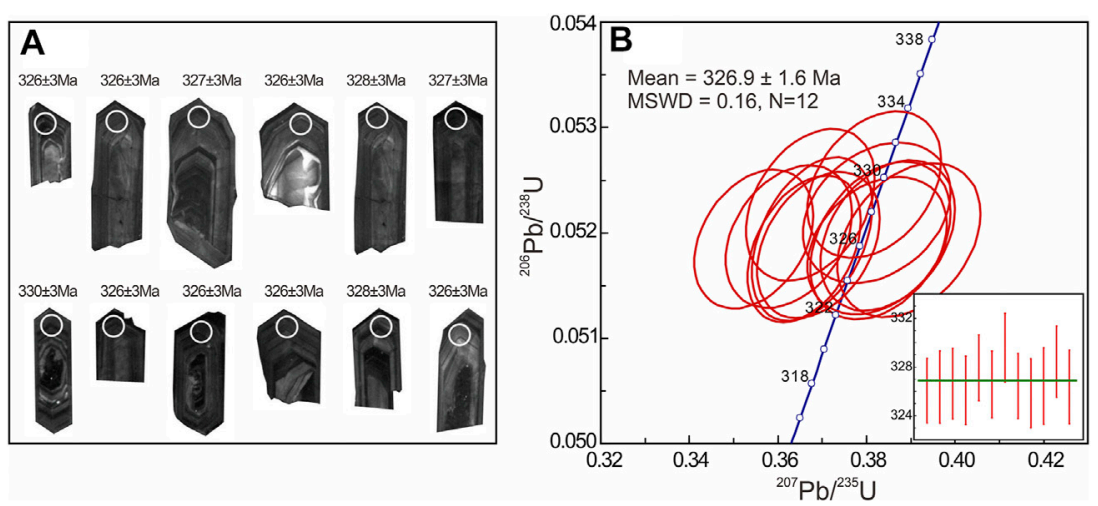

FIGURE 10 | Homogenisation temperature vs salinity diagrams for the measured fluid inclusions at the Heiyanshan deposits.

The fluid inclusions in the carbonate stage have lowtemperatures $\left(160^{\circ} \mathrm{C}\right)$, low salinities, low pressure, and can be classified as $\mathrm{NaCl}-\mathrm{H}_{2} \mathrm{O}$ fluids. The $\delta \mathrm{D}$ and $\delta^{18} \mathrm{O}$ values point to a meteoric source for the fluid inclusions. Thus, the precipitation of calcite represents the end of the magma-related mineralising hydrothermal fluids.

\section{Fluid Mixing and Precipitation of Tungsten}

The precipitation of scheelite can relate to cooling of the carrying fluids resulting in the decrease in $\mathrm{W}$-solubility, fluid mixing, and the buffering of $\mathrm{pH}$ levels neutral levels by reaction with carbonate rocks (e.g., Wood and Samson, 2000; Robb, 2005).

If simple cooling of the mineralised fluids led to tungsten deposition, it would be expected that the fluid's salinity would not change significantly ( $\mathrm{Ni}$ et al., 2015). However, the salinity decreases from the early prograde skarn to the late carbonate stage at Heiyanshan (Figure 11), which also excludes cooling as a key factor during the mineralising process.

Fluid boiling is also crucial for the deposition of tungstenbearing minerals because fluid boiling increase $p \mathrm{H}$ values that destabilize tungsten complexes, leading to tungsten precipitation (c.f. Jiang et al., 2019). The irregular presence of L- and V-type inclusions in scheelite from the oxide stage and quartz from the sulphide stage are characteristic of fluid boiling (Figures 7B,E).
However, the fluid inclusions homogenizing into different phases (liquid and gas) at similar temperatures is not obvious in the Heiyanshan deposit. Therefore, fluid boiling may not be the major cause to promote tungsten precipitation for the Heiyanshan deposit.

Einaudi et al. (1981) proposed that the key mechanism for precipitating scheelite in skarns is the increase of $\mathrm{Ca}^{2+} / \mathrm{H}^{+}$ due to reaction of $\mathrm{W}$-rich fluids with $\mathrm{Ca}$-rich lithologies, but this would include changes in the fluid's salinity (c.f. Wilkinson, 2001). The calculated $\delta^{18} \mathrm{O}_{\text {water }}$ and $\delta \mathrm{D}_{\text {water }}$ values for fluid inclusions in the prograde skarn at Heiyanshan plot near the edge of the magmatic box on the $\delta \mathrm{D}-\delta^{18} \mathrm{O}$ diagram (Figure 9), which is similar to that of the prograde skarn at Xiaobaishitou (Li et al., 2020b). The calculated $\delta^{18} \mathrm{O}_{\text {water }}$ and $\delta \mathrm{D}_{\text {water }}$ values for the carbonate stage plot closer to the meteoric water line (Figure 9), indicating the possible contribution of meteoric water. The fluids from sulphide stage have $\delta^{18} \mathrm{O}_{\text {water }}$ and $\delta \mathrm{D}_{\text {water }}$ values intermediate between those for the prograde skarn and carbonate stages, indicating a mixing of deep-sourced magmatic fluids with meteoric water.

Therefore, it is proposed that the fluid mixing during its reaction with carbonates are the major factors involved during the precipitation of scheelite at Heiyanshan deposit. 


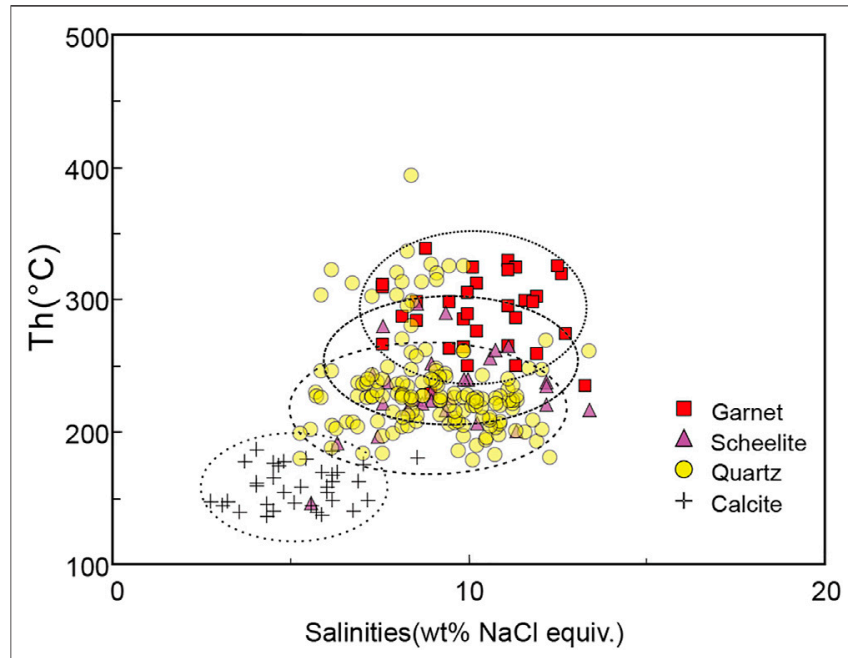

FIGURE 11 | Graphs showing (A) the calculated $\delta D$ and $\delta^{18} O$ values for fluids; and (B) homogenise temperatures and $\delta^{18} \mathrm{O}$ values for the mineralisation at the Heiyanshan deposit.

\section{Two Pulse of Tungsten Skarn in East Tianshan}

In recent years, several tungsten skarn deposits have been discovered in ETT, and the $\mathrm{WO}_{3}$ resources of these tungsten skarn deposits are more than 200,000 tons. The tungsten deposit in ETT is mainly distributed in the Central Tianshan Block and the South Tianshan Terrane (Figure 1). The Central Tianshan Block contains Xiaobaishitou W (-Mo), Shadong Rb-W, Heiyanshan W, Jiangshan W, Shadongdong W and Jinshan Au-W deposit. South Tianshan Terrane contains Zhongbao W, Sangshuyuanzi W and Wutonggou W deposits (Figure 1C). The metallogenic ages of these tungsten deposits can be divided into two stages, namely, Late Carboniferous and Early Triassic.

The Zhongbao and Sangshuyuanzi W deposits in Kumush area of South Tianshan Terrane are typical skarn tungsten deposits. The $\mathrm{W}$ orebodies occur in the contact zone between quartz schist and marble of the Arpishimaibulag Formation and monzogranite. Chen et al. (2013) reported that LA-ICP-MS zircon $\mathrm{U}-\mathrm{Pb}$ age of monzogranite from the Zhongbao and Sangshuyuanzi W deposits are $296 \pm 4 \mathrm{Ma}$ and $293 \pm 3 \mathrm{Ma}$, respectively, indicating that the tungsten deposits in the Kumush area of South Tianshan were mainly formed in the Late Carboniferous. We have recently discovered the Wutonggou tungsten skarn deposit in the South Tianshan Terrane. The orebody is stratiform and lenticular and occurs in the contact zone between quartz schist and marble of the Arpishimaibulag Formation and monzogranite. The LA-ICP-MS zircon U-Pb age of Wutonggou monzogranite is $313 \pm 2 \mathrm{Ma}$ (unpublished data), indicating an important Late Carboniferous tungsten mineralization in Kumush area, South Tianshan Terrane. This paper reports a LA-ICP-MS zircon U-Pb age of $326.9 \pm 1.6 \mathrm{Ma}$ for the biotite monzogranite in the Heiyanshan $\mathrm{W}$ deposit (Figure 10), which indicate a Late Carboniferous tungsten mineralization in the Central Tianshan Block.
The Xiaobaishitou and Heiyanshan $\mathrm{W}$ deposits are typical calcareous skarn deposits in Central Tianshan Block. The orebody is controlled by the contact zone of Mesoproterozoic Jianshanzi Formation of the Kawabulag Group and granite. Although Chen and Wang (1993) have reported whole rock $\mathrm{Rb}-\mathrm{Sr}$ isochron age of $294 \pm 49 \mathrm{Ma}$ for Xiaobaishitou W deposit, the easily disturbed $\mathrm{Rb}-\mathrm{Sr}$ isotopic systems make these data unreliable. Deng et al. (2017) reported that LA-ICP-MS zircon $\mathrm{U}-\mathrm{Pb}$ age of biotite granite and Mo-mineralized granite are $242 \pm 1.7 \mathrm{Ma}$ and $240.5 \pm 2.1 \mathrm{Ma}$, which constrains the emplacement age of the Xiaobaishitou granite more precisely as $240 \mathrm{Ma}$. Li et al. (2020b) obtained molybdenite Re-Os isochron age and muscovite ${ }^{40} \mathrm{Ar} /{ }^{39} \mathrm{Ar}$ plateau age of $253.0 \pm 2.7 \mathrm{Ma}$ and $247.6 \pm$ $2.3 \mathrm{Ma}$, respectively, which consistent with our results. The Shadong W deposit is unique magnesia skarn tungsten deposit in Central Tianshan Block. Tungsten skarn occurs in the contact zone between schist and gneiss of Kawabulag Group and granite. Chen et al. (2018) obtained a LA-ICP-MS zircon $\mathrm{U}-\mathrm{Pb}$ age of $239 \pm 2 \mathrm{Ma}$, indicating the development of largescale Early Triassic tungsten mineralization in the Central Tianshan Block.

In a word, ETT contains two pulse of tungsten metallogenic events of Late Carboniferous and Early Triassic. More and more tungsten deposits have been discovered in ETT, indicating that ETT will become an important tungsten metallogenic belt in northwest China.

\section{CONCLUSION}

The ore-foming process at the Heiyanshan W deposit in the East Tianshan consists of four stages, namely, prograde skarn stage, retrograde skarn stage, quartz-sulphide vein stage, and quartzcalcite vein stage.

The mineralised magma-related hydrothermal fluids related to the Heiyanshan W deposit progressed with the development of a skarn at moderate to low temperatures and salinities.

The decrease in the fluid's temperatures is probably due to a gradual introduction of meteoric water interacting with the hydrothermal fluid resulting in the deposition of scheelite.

The LA-ICP-MS zircon U-Pb age of $326.9 \pm 1.6 \mathrm{Ma}$ for the host biotite monzogranite, demonstrating that the Heiyanshan W system was formed in the Carboniferous, and the eastern Tianshan contains two pulse of tungsten metallogenic events.

\section{DATA AVAILABILITY STATEMENT}

The original contributions presented in the study are included in the article/supplementary material, further inquiries can be directed to the corresponding author.

\section{AUTHOR CONTRIBUTIONS}

$\mathrm{XD}$ and LB led the conception and design of the study. DX, XD, YW and XJ contributed the field work. DX and XC contributed 
the experiments of fluid inclusion and $\mathrm{H}-\mathrm{O}$ isotopic analysis. DX and XD wrote the first draft of the manuscript and interpreted the results with $\mathrm{LB}, \mathrm{XC}, \mathrm{YW}$, and XJ. All authors contributed to manuscript revision, read and approved it for publication.

\section{FUNDING}

This study is supported by the National Key Research and Development Program of China (2018YFC0604006), the National Natural Science Foundation of China (91962214 and

\section{REFERENCES}

Bodnar, R. J. (1993). Revised Equation and Table for Determining the Freezing point Depression of H2O-Nacl Solutions. Geochim. Cosmochim. Acta 57, 683-684. doi:10.1016/0016-7037(93)90378-a

Bottinga, Y., and Javoy, M. (1975). Oxygen isotope partitioning among the minerals in igneous and metamorphic rocks. Rev. Geophys. 13(2), 401-418. doi:10.1029/RG013i002p00401

Chang, Z. S., Shu, Q. H., and Meinert, L. D. (2019). Skarn Deposits of China. Soc. Econ. Geol. Spec. Publ. 22, 189-234. doi:10.5382/SP.22.06

Chen, Y. L., and Wang, Z. G. (1993). Geochemical Characteristics of East Tianshan Granitoid Rocks, Xinjiang, China. Geochimica 3, 288-302. (in Chinese with English abstract).

Chen, Y. J., Ni, P., Fan, H. R., Pirajno, F., Lai, Y., Su, W. C., et al. (2007). Diagnostic Fluid Inclusions of Different Types Hydrothermal Gold Deposits. Acta Petrol. Sin. 23, 2085-2108. (in Chinese with English abstract).

Chen, Y. J., Pirajno, F., Wu, G., Qi, J. P., Xiong, X. L., and Zhang, L. (2012). Epithermal Deposits in north Xinjiang, NW China. Int. J. Earth Sci. (Geol Rundsch) 101, 889-917. doi:10.1007/s00531-011-0689-4

Chen, C., Lu, X. B., Cao, X. F., Wu, C. M., and Zhu, J. (2013). Geochronology, Geochemistry and Geological Significance of Late Carboniferous-Early Permian Grnaites in Kumishi Area, Xinjiang. Earth Sci. 38 (2), 218-232. (in Chinese with English abstract).

Chen, C., Lü, X., Wu, C., Jiang, X., and Mao, C. (2018). Origin and Geodynamic Implications of Concealed Granite in Shadong Tungsten Deposit, Xinjiang, China: Zircon U-Pb Chronology, Geochemistry, and Sr-Nd-Hf Isotope Constraint. J. Earth Sci. 29, 114-129. doi:10.1007/s12583-0170808-7

Chen, X., Wu, Y. S., Zhao, K., Zhou, K., and Chen, Y. (2020). Age, Sediment Source and Tectonic Setting of the Ore-Hosting Jinwozi Formation at the Jinwozi Gold deposit in Beishan Orogen, NW China: Evidence from Detrital Zircon U-Pb Ages and Lu-Hf Isotopes. Ore Geology. Rev. 117, 103296. doi:10.1016/ j.oregeorev.2019.103296

Chen, Y. R. (2006). Geological Characteristics and Ore Genesis of the Xiaobaishitou Tungsten(-Molybdenum) deposit, Xinjiang. Gansu Metall. 28, 75-81. (in Chinese with English abstract).

Chi, G., Diamond, L. W., Lu, H., Lai, J., and Chu, H. (2021). Common Problems and Pitfalls in Fluid Inclusion Study: A Review and Discussion. Minerals 11, 7. doi: $10.3390 / \min 11010007$

Deng, X.-H., Wang, J.-B., Pirajno, F., Wang, Y.-W., Li, Y.-C., Li, C., et al. (2016). Re-Os Dating of Chalcopyrite from Selected mineral Deposits in the Kalatag District in the Eastern Tianshan Orogen, China. Ore Geol. Rev. 77, 72-81. doi:10.1016/j.oregeorev.2016.01.014

Deng, X.-H., Chen, Y.-J., Santosh, M., Wang, J.-B., Li, C., Yue, S.-W., et al. (2017). U-pb Zircon, Re-os Molybdenite Geochronology and Rb-Sr Geochemistry from the Xiaobaishitou W (-Mo) deposit: Implications for Triassic Tectonic Setting in Eastern Tianshan, NW China. Ore Geology. Rev. 80, 332-351. doi:10.1016/ j.oregeorev.2016.05.013

Deng, X.-H., Wang, J.-B., Pirajno, F., Mao, Q.-G., and Long, L.-L. (2020). A Review of Cu-Dominant mineral Systems in the Kalatag District, East Tianshan, China. Ore Geology. Rev. 117, 103284. doi:10.1016/j.oregeorev.2019.103284
42072106), the Geological Survey Project of China (1212011140056).

\section{ACKNOWLEDGMENTS}

We sincerely thank Profs. Yanjing Chen, Lianhui Dong, Xun Qu, Changzhi Wu, Haoshu Tang, Qiugen Li, Jing Zhang, Suwei Yue, Xiheng He assisted us with field investigations. We are grateful to Dengfeng Li for her help on zircon LA-ICP-MS U-Pb analyses. Comments and suggestions from editor and three reviewer greatly improved the quality of the paper.

Ding, T. P. (1988). Stable Isotope Studies on Several Typical Deposits in China. Beijing: Science and Technology Publishing House of Beijing, 21-44.

Einaudi, M., Meinert, L. D., and Newberry, R. J. (1981). Skarn Deposits. Econ. Geol. 75th Anniversary Volume, 317-391. doi:10.5382/av75.11

Goldstein, R. H., and Reynolds, T. J. (1994). Systematics of Fluid Inclusions in Diagenetic Minerals. Soc. Sediment. Geol. Short Course 31. doi:10.2110/scn.94.31

Gu, L. X., Hu, S. X., Yu, C. S., Zhao, M., Wu, C. Z., and Li, H. Y. (2001). Intrusive Activities during Compression-Extension Tectonic Conversion in the Bogda Intracontinental Orogen. Acta Petrol. Sin. 17, 187-198. (in Chinese with English abstract).

He, X.-H., Deng, X.-H., Bagas, L., Zhang, J., Li, C., and Zhang, W.-D. (2020). Geology, Geochronology, and Fluid Inclusion Studies of the Xiaorequanzi Volcanogenic Massive Sulphide $\mathrm{Cu}-\mathrm{Zn}$ deposit in the East Tianshan Terrane, China. Can. J. Earth Sci. 57 (12), 1392-1410. doi:10.1139/cjes-2019-0067

Hu, D. Q., Wang, D. K., Li, Y. F., Zhao, X. B., and Lin, L. (2016). The Geological Characteristics and Ore-Controlling Factors of the Heiyanshan Tungsten deposit. West China Prospecting Engineering, 28 (5), 170-174. (in Chinese with English abstract).

Jiang, H., Jiang, S.-Y., Li, W.-Q., Peng, N.-J., and Zhao, K.-D. (2019). Fluid Inclusion and Isotopic $(\mathrm{C}, \mathrm{H}, \mathrm{O}, \mathrm{S}$ and $\mathrm{Pb})$ Constraints on the Origin of Late Mesozoic Vein-type W Mineralization in Northern Guangdong, South China. Ore Geology. Rev. 112, 103007. doi:10.1016/ j.oregeorev.2019.103007

Jiang, X. (2016). Study on Metallogenic Regularity of Tungsten Deposits and Prospecting Target Optimization in the Area of Shadong in Hami. Xinjiang, Beijing: China University of Geosciences.

Lei, R.-X., Wu, C.-Z., Gu, L.-X., Zhang, Z.-Z., Chi, G.-X., and Jiang, Y.-H. (2011). Zircon $\mathrm{U}-\mathrm{Pb}$ Chronology and $\mathrm{Hf}$ Isotope of the Xingxingxia Granodiorite from the Central Tianshan Zone (NW China): Implications for the Tectonic Evolution of the Southern Altaids. Gondwana Res. 20, 582-593. doi:10.1016/j.gr.2011.02.010

Li, P., Lv, X. B., Chen, C., Cao, X. F., Ma, Y. L., and Su, Y. Y. (2011). Geochronology and Geochemical Characteristics of the Biotite-Granite in the Xiaobaishitou Tungsten deposit, East Tian Shan Mountains of Xinjiang and Their Geological Implications. Geol. Expl. 47, 543-554.

Li, D. F., Chen, H. Y., Sun, X. M., Fu, Y. M., Liu, Q. F., Xia, X. P., et al. (2019). Coupled Trace Element and SIMS Sulfur Isotope Geochemistry of Sedimentary Pyrite: Implications on Pyrite Growth of Caixiashan $\mathrm{Pb}-\mathrm{Zn}$ deposit. Geosci. Front. 10, 2177-2188. doi:10.1016/j.gsf.2019.05.001

Li, N., Yang, F., Zhang, Z., and Tang, L. (2019a). Petrogenesis of Early Devonian Granodiorite in the Xiaobaishitou W-(Mo) Ore District of East Tianshan, Northwest China, and Tectonic Implications: U-Pb Geochronological, Geochemical, and Sr-Nd Isotopic Evidence. Geol. J. 55 (1), 4302-4323. doi:10.1002/gj. 3668

Li, N., Yang, F., Zhang, Z., and Yang, C. (2019b). Geochemistry and Chronology of the Biotite Granite in the Xiaobaishitou W-(Mo) deposit, Eastern Tianshan, China: Petrogenesis and Tectonic Implications. Ore Geology. Rev. 107, 999-1019. doi:10.1016/j.oregeorev.2019.03.027

Li, N., Yang, F., and Zhang, Z. (2020a). Fluid Inclusions and Isotope (C, H, O, S, $\mathrm{He}$, and Ar) Study of the Xiaobaishitou Skarn W-(Mo) deposit, East Tianshan, NW China. Ore Geology. Rev. 122, 103520. doi:10.1016/ j.oregeorev.2020.103520

Li, N., Yang, F., Zhang, Z., and Li, C. (2020b). Dating the Xiaobaishitou Skarn W(Mo) deposit, Eastern Tianshan, NW China: Constraints from Zircon U-Pb, 
Muscovite 40Ar-39Ar, and Molybdenite Re-os System. Ore Geology. Rev. 124, 103637. doi:10.1016/j.oregeorev.2020.103637

Liu, Y., Hu, Z., Zong, K., Gao, C., Gao, S., Xu, J., et al. (2010). Reappraisement and Refinement of Zircon U-Pb Isotope and Trace Element Analyses by LA-ICPMS. Chin. Sci. Bull. 55 (15), 1535-1546. doi:10.1007/s11434-010-3052-4

Mao, Y.-J., Qin, K.-Z., Li, C., and Tang, D.-M. (2015). A Modified Genetic Model for the Huangshandong Magmatic Sulfide deposit in the Central Asian Orogenic Belt, Xinjiang, Western China. Miner. Deposita 50, 65-82. doi:10.1007/s00126-014-0524-5

Mao, J. W., Ouyang, H. G., Song, S. W., Santosh, M., Yuan, S. D., Zhou, Z. H., et al. (2019). Geology and Metallogeny of Tungsten and Tin Deposits in China, in Chang, Z., and Goldfarb, R.J., eds., Mineral Deposits of China. SEG Spec. Publ. 22, 411-482. doi:10.5382/SP.22.10

Meinert, L. D., Dipple, G. M., and Nicolescu, S. (2005). World skarn deposits: Economic Geology 100th Anniversary Volume. 299-336.

Muhtar, M. N., Wu, C.-Z., Brzozowski, M. J., Li, P., Yuan, X.-C., Wang, S.-M., et al. (2020). Geochronology, Geochemistry, and Sr-Nd-Pb-Hf-S Isotopes of the wall Rocks of the Kanggur Gold Polymetallic deposit, Chinese North Tianshan: Implications for Petrogenesis and Sources of Ore-Forming Materials. Ore Geology. Rev. 125, 103688. doi:10.1016/j.oregeorev.2020.103688

Ni, P., Wang, G.-G., Yu, W., Chen, H., Jiang, L.-L., Wang, B.-H., et al. (2015). Evidence of Fluid Inclusions for Two Stages of Fluid Boiling in the Formation of the Giant Shapinggou Porphyry Mo deposit, Dabie Orogen, Central China. Ore Geology. Rev. 65, 1078-1094. doi:10.1016/j.oregeorev.2014.09.017

O’Neil, J. R., Clayton, R.-N., Mayeda, T. K., et al. (1969). Oxygen isotope fractionation in divalent metal carbonates. J. Chem. Phys. 51, 5547-5558. doi:10.1063/1.1671982

Pan, J.-Y., Ni, P., and Wang, R.-C. (2019). Comparison of Fluid Processes in Coexisting Wolframite and Quartz from a Giant Vein-type Tungsten deposit, South China: Insights from Detailed Petrography and LA-ICP-MS Analysis of Fluid Inclusions. Am. Mineral. 104, 1092-1116. doi:10.2138/am2019-6958

Pirajno, F. (2009). Hydrothermal Processes and Mineral Systems. Netherlands: Springer, 1250p. doi:10.1007/978-1-4020-8613-7

Qin, K. Z., Fang, T. H., and Wang, S. L. (2002). Plate Tectonics Division, Evolution and Metallogenic Settings in Eastern Tianshan Mountains, NW China. Xinjiang Geol. 20, 302-308. (in Chinese with English abstract).

Robb, L., (2005). Introduction to Ore-Forming Processes, Blackwell Publishing. 382p., ISBN 0-632-06378-5.

Roedder, E. (1984). Fluid Inclusions. Washington, DC: Mineralogical Society of America, 644.

Sengör, A. M. C., Natalin, B. A., and Burtman, V. S. (1993). Evolution of the Altaid Tectonic Collage and Paleozoic Crustal Growth in Eurasia. Nature 364, 299-307.

Soloviev, S. G., and Kryazhev, S. (2017a). Geology, Mineralization, and Fluid Inclusion Characteristics of the Chorukh-Dairon W-Mo-Cu Skarn deposit in the Middle Tien Shan, Northern Tajikistan. Ore Geology. Rev. 80, 79-102. doi:10.1016/j.oregeorev.2016.06.021

Soloviev, S. G., and Kryazhev, S. G. (2017b). Geology, Mineralization, and Fluid Inclusion Characteristics of the Skrytoe Reduced-type W Skarn and Stockwork deposit, SikhoteAlin, Russia. Miner. Deposita 52, 903-928. doi:10.1007/s00126-016-0705-5

Soloviev, S. G. (2011). Geology, Mineralization, and Fluid Inclusion Characteristics of the Kensu W-Mo Skarn and Mo-W-Cu-Au Alkalic Porphyry Deposit, Tien Shan, Kyrgyzstan. Econ. Geology. 106, 193-222. doi:10.2113/econgeo.106.2.193

Soloviev, S. G. (2015). Geology, Mineralization, and Fluid Inclusion Characteristics of the Kumbel Oxidized W-Cu-Mo Skarn and Au-W Stockwork deposit in Kyrgyzstan, Tien Shan. Miner. Deposita 50, 187-220. doi:10.1007/s00126-014-0531-6

Tang, D., Qin, K., Su, B., Mao, Y., Evans, N. J., Niu, Y., et al. (2020). Sulfur and Copper Isotopic Signatures of Chalcopyrite at Kalatongke and Baishiquan: Insights into the Origin of Magmatic Ni-Cu Sulfide Deposits. Geochim. Cosmochim. Acta 275, 209-228. doi:10.1016/j.gca.2020.02.015

Wang, Y.-H., and Zhang, F.-F. (2016). Petrogenesis of Early Silurian Intrusions in the Sanchakou Area of Eastern Tianshan, Northwest China, and Tectonic Implications: Geochronological, Geochemical, and Hf Isotopic Evidence. Int. Geol. Rev. 58, 1294-1310. doi:10.1080/00206814.2016.1152516

Wang, J. B., Wang, Y. W., and He, Z. H. (2006). Ore Deposits as a Guide to the Tectonic Evolution in the East Tianshan Mountains, NW China. Geol. China 33, 461-469. (in Chinese with English abstract).
Wang, Y.-H., Zhang, F.-F., and Liu, J.-J. (2016). The Genesis of the Ores and Intrusions at the Yuhai Cu-Mo deposit in Eastern Tianshan, NW China: Constraints from Geology, Geochronology, Geochemistry, and Hf Isotope Systematics. Ore Geology. Rev. 77, 312-331. doi:10.1016/j.oregeorev.2016.03.003

Wang, Y., Chen, H., Han, J., Chen, S., Huang, B., Li, C., et al. (2018). Paleozoic Tectonic Evolution of the Dananhu-Tousuquan Island Arc belt, Eastern Tianshan: Constraints from the Magmatism of the Yuhai Porphyry $\mathrm{Cu}$ deposit, Xinjiang, NW China. J. Asian Earth Sci. 153, 282-306. doi:10.1016/ j.jseaes.2017.05.022

Wiedenbeck, M., Allé, P., Corfu, F., Griffin, W. L., Meier, M., Oberli, F., et al. (1995). Three Natural Zircon Standards for U-Th-Pb, Lu-Hf, Trace Element and REE Analyses. Geoanal. Res. 19, 1-23. doi:10.1111/j.1751908x.1995.tb00147.x

Wilkinson, J. J. (2001). Fluid Inclusions in Hydrothermal Ore Deposits. Lithos 55, 229-272. doi:10.1016/s0024-4937(00)00047-5

Windley, B. F., Alexeiev, D., Xiao, W., Kröner, A., and Badarch, G. (2007). Tectonic Models for Accretion of the Central Asian Orogenic Belt. J. Geol. Soc. 164, 31-47. doi:10.1144/0016-76492006-022

Wood, S. A., and Samson, I. M. (2000). The Hydrothermal Geochemistry of Tungsten in Granitoid Environments: I. Relative Solubilities of Ferberite and Scheelite as a Function of T, P, pH, and mNaCl. Econ. Geol. 95, 143-182. doi:10.2113/gsecongeo.95.1.143

Wu, C.-Z., Zhang, Z.-Z., Gu, L.-X., Tang, J.-H., and Lei, R.-X. (2010). Sr, Nd and O Isotopic Characters of Quartz Syenite in the Weiya Magmatic Complex from Eastern Tianshan in NW China: Melting of the Thickened Juvenile Lower Crust. Geochem. J. 44, 285-298. doi:10.2343/geochemj.1.0072

Wu, Y.-S., Zhou, K.-F., Li, N., and Chen, Y.-J. (2017). Zircon U-Pb Dating and Sr$\mathrm{Nd}-\mathrm{Pb}$-Hf Isotopes of the Ore-Associated Porphyry at the Giant Donggebi Mo deposit, Eastern Tianshan, NW China. Ore Geology. Rev. 81, 794-807. doi:10.1016/j.oregeorev.2016.02.007

Wu, C.-Z., Xie, S.-W., Gu, L.-X., Samson, I. M., Yang, T., Lei, R.-X., et al. (2018). Shear Zone-Controlled post-magmatic Ore Formation in the Huangshandong Ni-Cu Sulfide deposit, NW China. Ore Geology. Rev. 100, 545-560. doi:10.1016/ j.oregeorev.2017.02.015

Xiao, W., Windley, B. F., Allen, M. B., and Han, C. (2013). Paleozoic Multiple Accretionary and Collisional Tectonics of the Chinese Tianshan Orogenic Collage. Gondwana Res. 23, 1316-1341. doi:10.1016/j.gr.2012.01.012

Xiao, B., Chen, H., Hollings, P., Han, J., Wang, Y., Yang, J., et al. (2017). Magmatic Evolution of the Tuwu-Yandong Porphyry Cu belt, NW China: Constraints from Geochronology, Geochemistry and Sr-Nd-Hf Isotopes. Gondwana Res. 43, 74-91. doi:10.1016/j.gr.2015.09.003

Xiao, W., Song, D., Windley, B. F., Li, J., Han, C., Wan, B., et al. (2020). Accretionary Processes and Metallogenesis of the Central Asian Orogenic Belt: Advances and Perspectives. Sci. China Earth Sci. 63, 329-361. doi:10.1007/s11430-019-9524-6

Yu, P.-P., Zheng, Y., Qian, J.-H., and Lin, Z.-W. (2018). Geological, Geochronological and Geochemical Constraints on the Tianhu Iron deposit, Chinese Tianshan Orogen, NW China: A Modified Algomatype BIF deposit. Ore Geology. Rev. 100, 317-333. doi:10.1016/ j.oregeorev.2017.06.004

Zhang, L., Xiao, W., Qin, K., and Zhang, Q. (2006). The Adakite Connection of the Tuwu-Yandong Copper Porphyry belt, Eastern Tianshan, NW China: Trace Element and Sr-Nd-Pb Isotope Geochemistry. Miner. Deposita 41, 188-200. doi:10.1007/s00126-006-0058-6

Zhang, F.-F., Wang, Y.-H., Xue, C.-J., Liu, J.-j., and Zhang, W. (2019). Fluid Inclusion and Isotope Evidence for Magmatic-Hydrothermal Fluid Evolution in the Tuwu Porphyry Copper deposit, Xinjiang, NW China. Ore Geology. Rev. 113, 103078. doi:10.1016/j.oregeorev.2019.103078

Zhao, L., Chen, H., Hollings, P., and Han, J. (2019). Late Paleozoic Magmatism and Metallogenesis in the Aqishan-Yamansu belt, Eastern Tianshan: Constraints from the Bailingshan Intrusive Complex. Gondwana Res. 65, 68-85. doi:10.1016/j.gr.2018.08.004

Zheng, Y. F. (1993). Calculation of oxygen isotope fractionation in anhydrous silicate minerals. Geochim. Cosmochim. Acta 57, 1079-1091. doi:10.1016/00167037(93)90042-U

Conflict of Interest: Authors DX and XD were employed by the company Beijing Institute of Geology for Mineral Resources Co., Ltd. 
The remaining authors declare that the research was conducted in the absence of any commercial or financial relationships that could be construed as a potential conflict of interest.

The reviewer (YZ) declared a shared affiliation with several of the authors, (DX, JZ, $\mathrm{XC}, \mathrm{XH})$, to the handling editor at time of review.

Publisher's Note: All claims expressed in this article are solely those of the authors and do not necessarily represent those of their affiliated organizations, or those of the publisher, the editors and the reviewers. Any product that may be evaluated in this article, or claim that may be made by its manufacturer, is not guaranteed or endorsed by the publisher.

Copyright (c) 2021 Xue, Deng, Bagas, Chen, Wu and Jiang. This is an open-access article distributed under the terms of the Creative Commons Attribution License (CC $B Y)$. The use, distribution or reproduction in other forums is permitted, provided the original author(s) and the copyright owner(s) are credited and that the original publication in this journal is cited, in accordance with accepted academic practice. No use, distribution or reproduction is permitted which does not comply with these terms. 